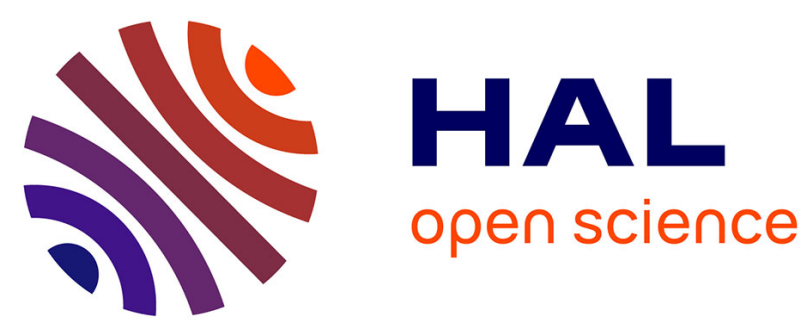

\title{
Thorough analysis of silicon substitution in biphasic calcium phosphate bioceramics: A multi-technique study
} S. Gomes, G. Renaudin, Adel Mesbah, Edouard Jallot, Christian Bonhomme, F. Babonneau, Jean-Marie Nedelec

\section{- To cite this version:}

S. Gomes, G. Renaudin, Adel Mesbah, Edouard Jallot, Christian Bonhomme, et al.. Thorough analysis of silicon substitution in biphasic calcium phosphate bioceramics: A multi-technique study. Acta Biomaterialia, 2010, 6 (8), pp.3264-3274. 10.1016/j.actbio.2010.02.034 . hal-00492332

\section{HAL Id: hal-00492332 https://hal.science/hal-00492332}

Submitted on 2 Jul 2021

HAL is a multi-disciplinary open access archive for the deposit and dissemination of scientific research documents, whether they are published or not. The documents may come from teaching and research institutions in France or abroad, or from public or private research centers.
L'archive ouverte pluridisciplinaire HAL, est destinée au dépôt et à la diffusion de documents scientifiques de niveau recherche, publiés ou non, émanant des établissements d'enseignement et de recherche français ou étrangers, des laboratoires publics ou privés.

\section{(c)(1)}

Distributed under a Creative Commons Attribution| 4.0 International License 


\title{
Thorough analysis of silicon substitution in biphasic calcium phosphate bioceramics: A multi-technique study
}

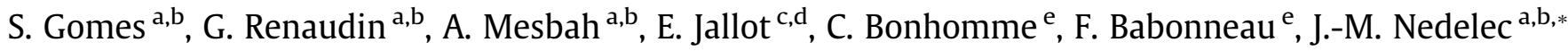 \\ ${ }^{a}$ Clermont Université, ENSCCF, Laboratoire des Matériaux Inorganiques, BP 10448, F-63000, Clermont-Ferrand, France \\ ${ }^{\mathrm{b}}$ CNRS, UMR 6002, F-63177 Aubière, France \\ ${ }^{c}$ Clermont Université, UBP, LPC, F-63177 Aubière, France \\ d CNRS, UMR 6533, F-63177 Aubière, France \\ ${ }^{\mathrm{e}}$ Université Pierre et Marie Curie - Paris 6 and CNRS, Collège de France, Laboratoire de Chimie de la Matière Condensée, 11 place Marcelin Berthelot 75005 Paris France
}

\begin{abstract}
Four samples of composition $\mathrm{Ca}_{10}\left(\mathrm{PO}_{4}\right)_{6-x}\left(\mathrm{SiO}_{4}\right)_{x}(\mathrm{OH})_{2-x}$, with $x=0.0,0.1,0.2$ and 0.5 , were prepared and characterized using powder X-ray and neutron powder diffraction, and ${ }^{1} \mathrm{H},{ }^{31} \mathrm{P}$ and ${ }^{29} \mathrm{Si}$ nuclear magnetic resonance (NMR) spectroscopy. The composition of the Si-substituted HAp phases was determined by joint Rietveld refinements from powder X-ray and powder neutron diffraction data. Taking into account electroneutrality, a chemical formula for the Si-substituted HAp phases with indication of the incorporated silicate amount is proposed. Solid-state ${ }^{29} \mathrm{Si}$ NMR confirms the presence of only $Q_{0}$ species, in good agreement with the presence of substituted HAp and $\beta$-TCP phases only. Thanks to NMR spectroscopy, two types of protons in the Si-substituted HAp phase were identified, the new site corresponding to species engaged in hydrogen bonding with silicate anions. This allowed further refinement of the formulae for these phases with very good quantitative agreement for populations derived from the refinement and integration of NMR data.
\end{abstract}

\section{Introduction}

Biphasic calcium phosphate $(\mathrm{BCP})$ ceramics, composed of a mixture of hydroxyapatite $\left(\mathrm{HAp}, \mathrm{Ca}_{10}\left(\mathrm{PO}_{4}\right)_{6}(\mathrm{OH})_{2}\right)$ and $\beta$-tricalcium phosphate $\left(\beta-\mathrm{TCP}, \beta-\mathrm{Ca}_{3}\left(\mathrm{PO}_{4}\right)_{2}\right)$, are interesting candidates in reconstructive surgery. Bone mineral mass is dominated by nanocrystalline multisubstituted calcium phosphate apatite [1$3]$. The type and amount of ionic substitutions in the apatite phase of bone vary from the weight per cent (wt.\%) level (for carbonate substitution [4]) to the parts per million (ppm) level (for strontium or barium substitutions, for example [5]). The role of many of these ionic species in hard tissues is not fully understood owing to the difficulties encountered in monitoring and quantifying their amounts, which vary according to dietary alteration, and to physiological and pathological causes [6]. However, it is accepted that these different ions play a major role in the biochemistry of bones, enamel and dentin [7]. HAp is widely used as a biomaterial in clinical applications (bioactive HAp coatings on metallic implants $[8,9]$, porous HAp ceramic implants to facilitate bone ingrowth [10], or inorganic filler in a ceramic-polymer composite biomate-

* Corresponding author. Address: Clermont Université, ENSCCF, Laboratoire des Matériaux Inorganiques, BP 10448, F-63000, Clermont-Ferrand, France Tel.: +33 4 734071 95; fax: +33473405328.

E-mail address: j-marie.nedelec@univ-bpclermont.fr (J.-M. Nedelec). rial [11]) owing to its high biocompatibility and osteoconductivity. It is therefore essential to improve HAp in vivo bioactivity by increasing its solubility in order to accelerate the subsequent crystallization of apatite crystals, cell adhesion and collagen formation. When bioactive glasses are used, these reactions are very rapid and have been reported to occur within minutes of implantation or contact with physiological solutions [12], but the great advantage of HAp materials is their chemical similarity to the bone inorganic component. The most common example of this approach is the preparation of carbonated-substituted HAp $[13,14]$. Several studies have demonstrated the beneficial effect of the incorporation of silicon in HAp (in vitro enhancement and stimulation of the osteoblast-like cell activity, and in vivo increase in the dissolution rate) [15-19]; [20 for a review]. Silicon is involved in the early stage of bone calcification, and the presence of silicon favours bone formation and calcification [18,21-23]. Interestingly, these effects have been critically discussed very recently by Bohner [24], putting forward the lack of deep understanding of the effect of $\mathrm{Si}$ doping on the materials themselves and thus questioning the origin of the claimed effect in biological conditions. Another crucial point raised in the paper is the need for accurate local information about substituting ions and their fate upon interactions in biological conditions. In particular, two very distinct situations discussed in Ref. [24] can be considered, depending on the real incorporation of silicon in the structure of 
the apatite or failure to incorporate. If the silicon is weakly bonded to the ceramic, some silicon can be released in the biological fluids and then have an effect on cellular behaviour as documented in the literature; in that case, the material acts mainly as a silicon-delivery system. If the silicon is structurally incorporated in the crystalline phases, this claim is hard to follow, because the Si-HAp is believed to be very stable. In this case, only modifications of the HAp properties (crystallite size, crystallinity, surface roughness, surface charges) could explain different behaviour in solution. In this case, this is an indirect effect of silicon doping affecting the crystalline structure of the material. Another possibility for increasing calcium phosphate solubility is to mix the HAp phase with appreciable levels of a more resorbable calcium phosphate phase, such as $\beta$-TCP, to form so-called BCP ceramics [25-29]. In this case, if the silicon is substituted in both phases, the two previously mentioned effects could combine owing to the high solubility of TCP phase. It is thus of major importance to follow carefully the fate of silicon substitution in these types of ceramics.

In the present work, a series of silicon-substituted BCP ceramics, with increasing weight content of silicon (0.0-1.4 wt.\% Si), was synthesized following the aqueous precipitation method largely used in the literature and described by Gibson et al. [15]. A fine structural description of the silicon-substituted BCP samples is needed to understand and improve the material performance. Such a structural description is important for the HAp phase, whose structure can present several non-stoichiometries due to calcium deficiency, presence of $\mathrm{HPO}_{4}^{2-}$ anion, replacement of hydroxyl by oxygen or vacancy [30]. The originality of this work is to propose a combined approach using both diffraction techniques (X-rays and neutrons) and local and selective technique, namely solid-state NMR spectroscopy. The later is particularly powerful for localizing the silicate ions inside the phosphocalcic phases and probing their spatial proximity with other nuclei.

\section{Materials and methods}

\section{1. $S i_{x}-B C P$ syntheses $(x=0.0,0.1,0.2$ and 0.5$)$}

Four samples of composition $\mathrm{Ca}_{10}\left(\mathrm{PO}_{4}\right)_{6-x}\left(\mathrm{SiO}_{4}\right)_{x}(\mathrm{OH})_{2-x}$, with $x=0.0,0.1,0.2$ and 0.5 , were synthesized using the aqueous precipitation method [15] which led, according to the literature, either to single Si-doped HAp phase or to BCP (Si-doped mixture of HAp and $\beta$-TCP phases) $[20,31,32]$. The syntheses were repeated several times and are reproducible from XRD data. This acid-base neutralization reaction is by far the most often encountered one in the literature. The starting materials used were calcium hydroxide $\left(\mathrm{Ca}(\mathrm{OH})_{2}\right.$, Riedel-de Haën), orthophosphoric acid $\left(\mathrm{H}_{3} \mathrm{PO}_{4}\right.$, SigmaAldrich) and silicon acetate $\left(\mathrm{Si}\left(\mathrm{CH}_{3} \mathrm{COO}\right)_{4}\right.$, Aldrich). The synthesized samples are named $\mathrm{Si}_{x}-\mathrm{BCP}$, with $x$ the value of the nominal silicate substitution $(x=0.0,0.1,0.2$ and 0.5$)$. The appropriate quantities of reactants to prepare $\mathrm{Si}_{x}-\mathrm{BCP}$ were calculated assuming that silicate would substitute for phosphate according to the mechanism $\left[\mathrm{PO}_{4}\right]^{3-}+\mathrm{OH}^{-} \leftrightarrow\left[\mathrm{SiO}_{4}\right]^{4-}$, to ensure charge imbalance. The targeted nominal composition is thus $\mathrm{Ca}_{10}\left(\mathrm{PO}_{4}\right)_{6-x}\left(\mathrm{SiO}_{4}\right)_{x}(\mathrm{OH})_{2-x}$. The precipitation reaction was carried out at room temperature under stirring, and the $\mathrm{pH}$ was maintained at $10.5-11.0$ by the addition of ammonium hydroxide solution. After the reactants were mixed, the suspension was aged overnight. The resulting precipitate was filtered and dried overnight at $80^{\circ} \mathrm{C}$. The four as-prepared powders were heated at $1100{ }^{\circ} \mathrm{C}$ for $15 \mathrm{~h}$ (with a heating rate of $4^{\circ} \mathrm{C} \mathrm{min}^{-1}$ ).

The chemical compositions of all the samples were determined by inductively coupled plasma atomic emission spectroscopy (ICPAES).

\subsection{Analytical techniques}

\subsubsection{X-ray diffraction and neutron powder diffraction}

Powder X-ray diffraction (PXRD) patterns were recorded on an X'Pert Pro Philips diffractometer, with $\theta-\theta$ geometry, equipped with a solid detector X-Celerator, a graphite back-end monochromator, and using $\mathrm{Cu} \mathrm{K} \alpha$ radiation $(\lambda=1.54184 \AA$ ). PXRD patterns were recorded at room temperature in the interval $3^{\circ}<2 \theta<120^{\circ}$, with step size $\Delta 2 \theta=0.0167^{\circ}$ and counting time 30 s per step. A PXRD pattern was collected from pure Si standard using the same experimental conditions in order to extract the instrumental resolution function to improve the peak profile fitting and to extract intrinsic microstructural parameters of both HAp and $\beta$-TCP phases.

Neutron powder diffraction (NPD) experiments were performed on D1B at ILL (Grenoble, France) at room temperature. The samples ( $\sim 2 \mathrm{~g}$ mass) were enclosed in cylindrical vanadium containers with inner diameter $8 \mathrm{~mm}$ and measured at a wavelength of $\lambda=2.52 \AA$ using graphite monochromators, in the $2 \theta$ range $10-90^{\circ}$ with step size $2 \theta=0.2^{\circ}$. The transmission factor was calculated $(\mu R=0.15)$ and the data corrected accordingly. The patterns showed the same phases as those observed by XRD. The low amount of hydrogen atoms in the samples allows NPD patterns with acceptable background to be recorded without preparing deuterated samples. The high neutron scattering contrast of hydrogen atoms, due to the negative neutron scattering length of $-3.74 \mathrm{fm}$, allows refinement of their localization and site occupancies with good accuracy.

\subsubsection{Joint Rietveld refinements}

Joint Rietveld refinements based on the simultaneous use of $\mathrm{X}$ ray and neutron data were performed for each sample with the FullProf.2k Multi-Pattern program [33]. This technique reaches good accuracy in the refinement of $\mathrm{Ca}, \mathrm{P}, \mathrm{O}$ and $\mathrm{H}$ sites (site positions and site occupancies). Nevertheless, the cationic distribution on the P sites (due to Si substitution) was not accessible here. The use of a high-resolution-high-intensity neutron diffractometer is needed to refine $\mathrm{Si}$ atoms in calcium phosphate phases ( $\mathrm{Si}$ atom presents a weak neutron scattering contrast and no X-ray scattering contrast with $\mathrm{P}$ atom). The initial structural parameters of HAp, $\mathrm{Ca}_{10}\left(\mathrm{PO}_{4}\right)_{6}(\mathrm{OH})_{2}$, were taken from Ref. [34]: space group $P 6_{3} / \mathrm{m}$, $Z=2, a=9.4218 \AA$ and $c=6.8813 \AA$, seven independent atomic positions: two $\mathrm{Ca}$ positions in sites $4 f(z=0.0007)$ and $6 h$ $(x=0.2465, y=0.9933)$, one $\mathrm{P}$ position in site $6 h(x=0.3968$, $y=0.3693)$, and four $\mathrm{O}$ positions in sites $6 h(x=0.331, y=0.480$ and $x=0.579, y=0.455), 12 i(x=0.3394, y=0.2569, z=0.0694)$ and $4 e$ ( $z=0.192$ with a half occupancy factor). The initial structural parameters of $\beta-\mathrm{TCP}, \mathrm{Ca}_{3}\left(\mathrm{PO}_{4}\right)_{2}$, were taken from Ref. [35]: space group $R 3 c, Z=21, a=10.4352 \AA$ and $c=37.4029 \AA$, 18 independent atomic positions: five Ca positions (three in site $18 \mathrm{~b}$ and two in site $6 a$, one with a partial occupancy factor), three $P$ positions (two in site $18 b$ and one in site $6 a$ ), and 100 positions (nine in site $18 b$ and one in site $6 a$ ). In the course of refinement, two hydrogen positions were introduced for the HAp phase: (1) a hydrogen atom from the hydroxyl group in the Wyckoff position $4 e$ ( $z=0.073$ with a half occupancy factor) [36]; and (2) a hydrogen atom from the $\mathrm{HPO}_{4}^{2-}$ anion in the Wyckoff position $6 h(x=0.4746$, $y=0.1666$ with a very small occupancy factor of 0.05 ) [30]. The following parameters were first refined: scale factors, zero shift, line profile parameters, lattice parameters, preferential orientations and asymmetry parameters. In the second step, thermal displacement factors were refined (three thermal displacement values were considered: one for $\mathrm{Ca}$, one for $\mathrm{P}$ and one for $\mathrm{O}$ ) as well as atomic coordinates when allowed by a sufficient weight of the phase (HAp phase for the four samples, and $\beta$-TCP phase for $\mathrm{Si}_{0.2^{-}}$ $\mathrm{BCP}$ and $\mathrm{Si}_{0.5}$-BCP samples). Site occupancies of calcium sites, phosphate group, oxygen and hydrogen atoms of hydroxyl group and of 
$\mathrm{HPO}_{4}^{2-}$ anion were systematically checked in the final runs. Ca1 site occupancy was found to deviate weakly from unity, unlike Ca2 site occupancy (which was fixed at unity). Occupancy of phosphate anion also deviated weakly from unity. Refinements of the oxygen and hydrogen sites occupancy from the hydroxyl group show the presence of both $\mathrm{O}^{2-}$ and $\mathrm{OH}^{-}$anions, as well as small amounts of vacancies. Occupancy factors from the hydrogen atom from the $\mathrm{HPO}_{4}^{2-}$ anion were close to zero. Only one soft distance constraint was applied in the case of the $\mathrm{Si}_{0.5}$ - $\mathrm{BCP}$ sample for the position refinement of hydrogen atom from the hydroxyl group due to too short a distance of $0.6(1) \AA ̊$ obtained without constraint (the applied soft constraint was an interatomic distance $d_{\mathrm{O}-\mathrm{H}}=0.85(5) \AA$, and the refined value was 0.79(6) $\AA$ ). Microstructural parameters were also extracted from the Rietveld refinement procedure as described in previous work $[29,36]$.

\subsubsection{NMR spectroscopy}

NMR spectra were recorded on an AVANCE 300 Bruker spectrometer $(7.05 \mathrm{~T})$ using cross-polarization magic angle spinning (CP-MAS) probeheads with $7 \mathrm{~mm}$ rotors spinning at $5 \mathrm{kHz}\left({ }^{29} \mathrm{Si}\right)$ or with $4 \mathrm{~mm}$ rotors spinning at $14 \mathrm{kHz}\left({ }^{31} \mathrm{P},{ }^{1} \mathrm{H}\right)$. The ${ }^{1} \mathrm{H}$ spectra were recorded with a recycle delay of $5 \mathrm{~s}$ for a $90^{\circ}$ excitation pulse $(5 \mu \mathrm{s})$. The ${ }^{31} \mathrm{P}$ spectra were recorded using $45^{\circ}$ pulse excitation $(1.9 \mu \mathrm{s})$ and a cross-polarization (CP) sequence with a square profile of the ${ }^{31} \mathrm{P}$ RF pulse during spin-lock (RF field of $52 \mathrm{kHz}$ ), and ${ }^{1} \mathrm{H}$ decoupling during acquisition using SPINAL-64. The ${ }^{1} \mathrm{H}-{ }^{31} \mathrm{P}$ heteronuclear correlation (HETCOR) experiments were recorded for a contact time of $900 \mu \mathrm{s}$ (32 transients and $108 t_{1}$ values). For the ${ }^{29} \mathrm{Si}$ MAS-NMR spectra, $45^{\circ}$ pulse excitation was used with a recycle delay of $60 \mathrm{~s}$. Between 5000 and 6000 transients were accumulated. A ${ }^{29} \mathrm{Si}-\left\{{ }^{1} \mathrm{H}\right\}$ CP-MAS experiment was performed for one sample with a contact time of $5 \mathrm{~ms}$.

NMR spectra were recorded for the undoped sample and for the two doped samples with the highest amount of silicon.

\section{Results and discussion}

\subsection{Elementary and phase compositions}

Chemical analyses (Table 1) of the silicon-substituted BCP samples deviate weakly from the expected nominal compositions. Experimental $\mathrm{Ca} /(\mathrm{P}+\mathrm{Si})$ and $x$ values are still above the expected values when silicon is added to the synthesis solutions. The experimental $\mathrm{Ca} /(\mathrm{P}+\mathrm{Si})$ and $x$ values indicate that the synthesized powder did not contain the whole quantities of silicon introduced during the synthesis. The higher silicon substitution level, the larger the gap between experimental and nominal composition: $x=0.09$ instead 0.1 for $\mathrm{Si}_{0.1}-\mathrm{BCP}, x=0.15$ instead 0.2 for $\mathrm{Si}_{0.2}-\mathrm{BCP}$, and $x=0.39$ instead 0.5 for $\mathrm{Si}_{0.5}-\mathrm{BCP}$. Such a difference between nominal and experimental chemical compositions could be explained by the consequent washing process applied on the as-synthesized poorly crystallized powder.
A representative plot of the Rietveld refinement of the as-prepared samples is shown in Fig. 1 for $\mathrm{Si}_{0.5}$-BCP sample. PXRD analysis clearly show that the four as-prepared powders are single phase, composed of HAp with very small crystallite size (as evidenced by the extremely broad diffraction peaks in the powder patterns). Rietveld refinements indicate an average coherent domain size $\sim 100 \AA$ for the as-prepared samples with an elongated prismatic morphology (with a basal dimension $\sim 70$ Å and height $\sim 140 \AA$ along the hexagonal axis).

Fig. 2 shows details $\left(20^{\circ}<2 \theta<60^{\circ}\right)$ of the PXRD patterns recorded for the samples heat treated at $1100^{\circ} \mathrm{C}$. PXRD patterns indicate that the four samples are BCP, composed of different amounts of well-crystallized HAp and $\beta$-TCP phases. Fig. 3 shows an example illustrating joint Rietveld refinement performed for the $\mathrm{Si}_{0.5}-\mathrm{BCP}$ sample on both X-ray and neutron diffraction patterns. Quantitative results from the Rietveld analyses are indicated in Table 2.

The amount of $\beta$-TCP is dependent on the silicon substitution level, as shown in Fig. 4. Unsubstituted powder from $\mathrm{Si}_{0.0}-\mathrm{BCP}$ presents a small amount of $\beta$-TCP ( $9 \mathrm{wt} . \%$ ), and this amount increases continuously with the amount of silicon to reach $40 \mathrm{wt} . \%$ in $\mathrm{Si}_{0.5}$-BCP. When the $x$ value is increased, a weak decrease in the crystallinity of the HAp phase (weak broadening of the HAp diffraction peaks) is observed.

\subsection{Joint Rietveld refinement results}

Rietveld refinement results indicate that silicon enters the HAp phase. Variations in lattice parameters $a$ and $c$ and in unit cell volume are dependent on the Si-substitution level. Table 2 and Fig. 5 show that the unit cell volume of HAp increases when silicon is added during the synthesis. In agreement with interatomic distances $\left(d_{\mathrm{Si}-\mathrm{O}}\right.$ of $1.66 \AA$ in silicate anion is longer than $d_{\mathrm{P}-\mathrm{O}}$ of $\sim 1.57 \AA$ in phosphate anion) the substitution of silicate for phosphate led to an increase in the unit cell volume, as mentioned in the literature [37-39]. Work by Gibson et al. [15] and Arcos et al. [30] show a quite invariant unit cell volume of HAp when substituted by silicon (see Fig. 5c). The variation in lattice parameter $c$ shows a more homogeneous increase when silicon is introduced in the HAp phase (see Fig. 5b). Only data from Arcos et al. [30] disagree with this observation, but their silicon-substituted HAp sample was prepared by the ceramic method in contrast to all other studies based on silicon-substituted HAp phases synthesized via a precipitation in solution (either the aqueous method $[15,37,39]$ and this work, or the sol-gel method [38]). Variation in the lattice parameter $a$ from these different studies is highly heterogeneous (see Fig. 5a), increasing ([38] and this work), invariant [30,37,39] or decreasing [15] with the $x$ nominal value. Such heterogeneous evolution of the basal hexagonal unit cell volume has a repercussion on the variation in the unit cell volume. This is true in the case of data from Gibson et al. [15], which present a decreasing unit cell volume in the Si-substituted HAp phase, in contrast to other data from samples prepared via a wet method. These observations illustrated in Fig. 5 clearly indicate (1) that the variation in the lattice

Table 1

Nominal and experimental (determined by ICP-AES) compositions of elemental oxide $\mathrm{CaO}, \mathrm{P}_{2} \mathrm{O}_{5}$ and $\mathrm{SiO}_{2}$ in the synthesized samples.

\begin{tabular}{|c|c|c|c|c|c|c|c|c|c|c|}
\hline \multirow[t]{2}{*}{ Sample } & \multicolumn{5}{|c|}{ Nominal composition } & \multicolumn{5}{|c|}{ Experimental composition } \\
\hline & $\mathrm{CaO}$ (wt.\%) & $\mathrm{P}_{2} \mathrm{O}_{5}$ (wt.\%) & $\mathrm{SiO}_{2}$ (wt.\%) & $\mathrm{Ca} /(\mathrm{P}+\mathrm{Si})$ & $x^{\mathrm{a}}$ & $\mathrm{CaO}$ (wt.\%) & $\mathrm{P}_{2} \mathrm{O}_{5}$ (wt.\%) & $\mathrm{SiO}_{2}$ (wt.\%) & $\mathrm{Ca} /(\mathrm{P}+\mathrm{Si})$ & $x^{\mathrm{b}}$ \\
\hline $\mathrm{Si}_{0.0}-\mathrm{BCP}$ & 56.84 & 43.16 & - & 1.67 & 0.0 & 57.01 & 42.99 & - & 1.68 & 0.00 \\
\hline $\mathrm{Si}_{0.1}-\mathrm{BCP}$ & 56.90 & 42.49 & 0.61 & 1.67 & 0.1 & 56.80 & 42.65 & 0.55 & 1.66 & 0.09 \\
\hline $\mathrm{Si}_{0.2}-\mathrm{BCP}$ & 56.97 & 41.81 & 1.22 & 1.67 & 0.2 & 57.00 & 42.69 & 0.93 & 1.65 & 0.15 \\
\hline $\mathrm{Si}_{0.5}-\mathrm{BCP}$ & 57.16 & 39.78 & 3.06 & 1.67 & 0.5 & 57.83 & 39.86 & 2.35 & 1.63 & 0.39 \\
\hline
\end{tabular}

a $x$ Value from the nominal used composition $\mathrm{Ca}_{10}\left(\mathrm{PO}_{4}\right)_{6-x}\left(\mathrm{SiO}_{4}\right)_{x}(\mathrm{OH})_{2-x}$.

b Experimental $x$ value from the chemical analyses. 


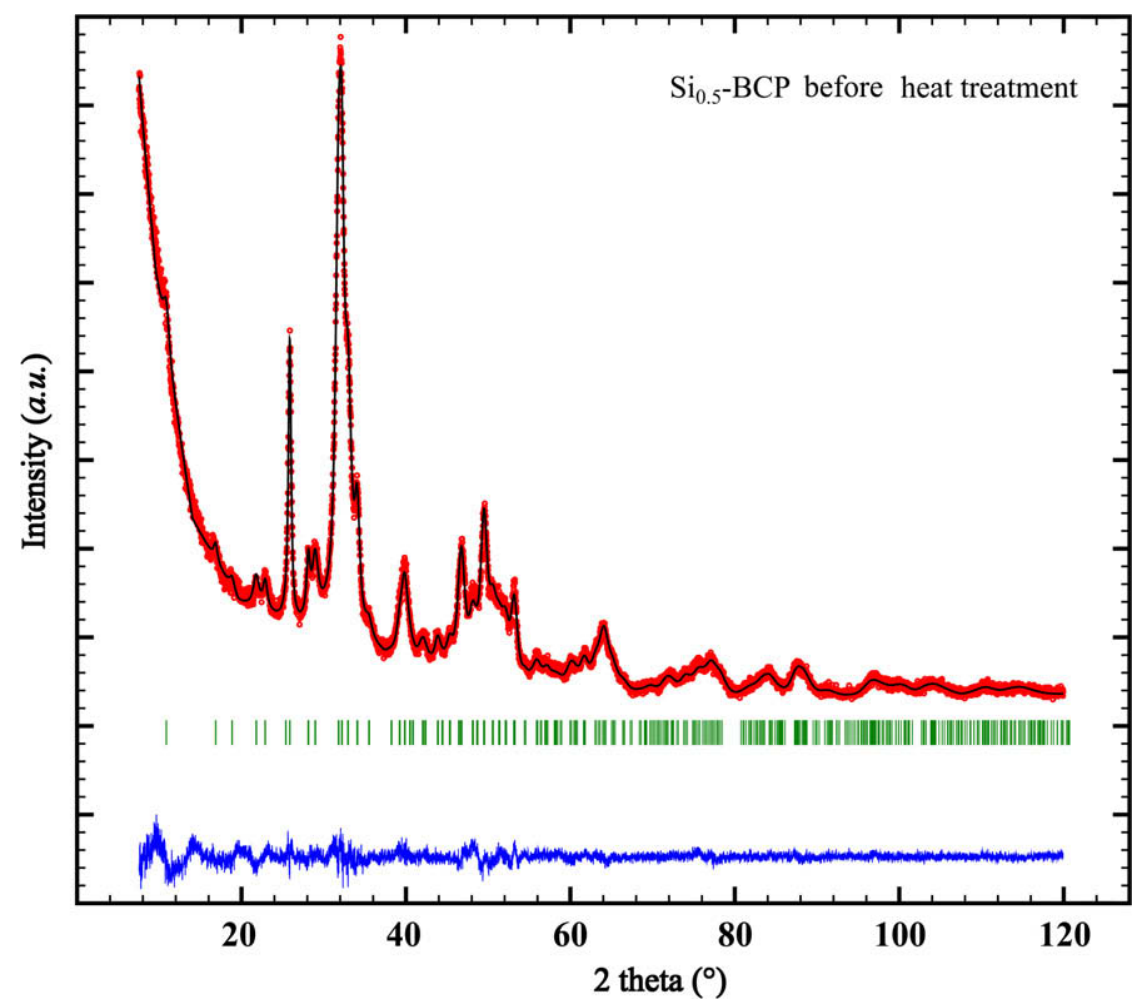

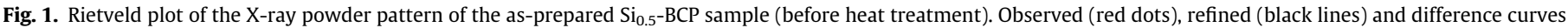
(blue line) with the HAp Bragg peak positions (green ticks).

parameter $c$ is a good indicator of the silicon substitution level (in contrast to the lattice parameter $a$, and a better indicator than the largely used unit cell volume), and (2) that wet (precipitation in solution) and dry (ceramic [30]) methods led to different materials. Insertion of silicon atoms into the HAp structure led to a decrease in the apparent coherent domain size (Table 2 ) as already observed in the case of strontium substitution in HAp [40]. The crystallinity of HAp samples is preserved, but the average crystallite size decreases from $>2200 \AA$ in the silicon-free $\mathrm{Si}_{0.0}-\mathrm{BCP}$ sample to $1250 \AA$ in the $\mathrm{Si}_{0.5}$-BCP sample. The decrease in the HAp crystallite size is concomitant with the increasing amount of $\beta$-TCP phase. When introduced in the HAp structure, silicon destabilizes its crystallization in favour of crystallization of $\beta$-TCP. The lattice parameters of the hexagonal lattice of $\beta$-ТCP (Table 2) increase when silicon is added. Fig. 6 reports the evolution of unit volume per Ca atom for both HAp (unit cell volume divided by 10) and $\beta$-TCP (unit cell volume divided by 63) phases. The gap in linearity encountered for the $\beta$-TCP phase must certainly be explained by its low amount by weight in the $\mathrm{Si}_{0.0}$ - $\mathrm{BCP}$ and $\mathrm{Si}_{0.1}$-BCP samples (Table 2). Comparison of these unit volume variations for the two phases indicates that silicon atoms are also inserted in the $\beta$-TCP structure. Silicon substitution for phosphate seems to be on the same order of magnitude for both phases, and perhaps more significant for $\beta$-TCP (as the slope of the linear fitting for $\beta$-TCP is higher than that for HAp).

Attempts to locate Si atom in both phases failed owing to insufficient scattering contrast between $\mathrm{P}$ and $\mathrm{Si}$, even using neutron diffraction data. In the case of the HAp structure, it is generally admitted that silicon substitutes the unique phosphorous site (P1). One phosphate $\mathrm{PO}_{4}^{3-}$ is replaced by one silicate $\mathrm{SiO}_{4}^{4-}$. The charge imbalance is then ensured either by the departure of a hydroxyl group with vacancy creation [15] or by hydroxylation of an $\mathrm{O}^{2-}$ anion as in the case of the oxy-hydroxyapatite phase [30]. The case of $\beta$-TCP is less trivial, as three crystallographic independent phosphorous sites are present. Attempts to localize Si atoms in
$\beta$-TCP phase during the joint Rietveld refinement always indicate the presence of a silicon atom in the P2 site of $\beta$-TCP (about $20 \%$ of $\mathrm{Si}$ would substitute for the P2 site in the $\mathrm{Si}_{0.5}-\mathrm{BCP}$ sample). Nevertheless, owing to the extremely high standard deviation value of this refined silicon occupancy (standard deviation and refined value were equivalent), the results are not considered here. A highresolution-high-intensity neutron diffractometer is needed for accurate refinement of the silicon insertion in these calcium phosphate phases. Such experiments are under way. The use of ${ }^{29} \mathrm{Si}$ NMR spectroscopy is also of great interest for differentiating, locating and quantifying the different types of silicon population, as well as for eventually identifying the presence of silica-gel, as reported by Gasquères et al. [41]. The results are discussed in Section 3.4. Despite the known $\alpha$-TCP stabilizing feature of Si [20], only the $\beta$-TCP polymorph was found in the BCP sample (no trace of $\alpha$-TCP was observed on the diffraction patterns). The absence of $\alpha$-TCP in the samples indicates a relatively low silicon substitution in the TCP phase, much less than 10 at.\% of Si substituted for P [42].

The tetrahedral distortion index $\left(\mathrm{TDI}=\frac{1}{6} \sum_{i=1}^{6}\left|\mathrm{OPO}_{i}-\mathrm{OPO}_{m}\right|\right.$, with $\mathrm{OPO}_{i}$ each of the six angles between the central $\mathrm{P}$ atom and its four oxygen atoms, and $\mathrm{OPO}_{m}$ their average) is mentioned in the literature as a potential indicator of the Si-substitution level in the HAp phase $[15,30,37]$. TDI calculation from the data (see Table 3) did not correlate with the silicon substitution level. In the first step, the TDI increases weakly from $1.47\left(\mathrm{Si}_{0.0^{-}} \mathrm{BCP}\right)$ to $1.54\left(\mathrm{Si}_{0.1^{-}}\right.$ $\mathrm{BCP})$, and then decreases below unity $\left(0.83\right.$ for $\mathrm{Si}_{0.2}$-BCP and 0.97 for $\mathrm{Si}_{0.5}-\mathrm{BCP}$ ) indicating a less distorted phosphate tetrahedron when substituted by silicate. Contrary to these observations, the phosphate distortion values from the literature increase when silicon is introduced in HAp: Gibson et al. observed a large increase in TDI from 1.85 for $x=0.0$ to 2.75 for $x=0.4$ [15], and Arcos et al. indicated a weaker increase from 1.93 for $x=0.0$ to 2.10 for $x=0.33$ [30]. TDI is definitively not an accurate index for following the silicon substitution level, as values range between 1.47 (this work) and 1.93 [30] in silicon-free HAp, and as silicon insertion led either to a 


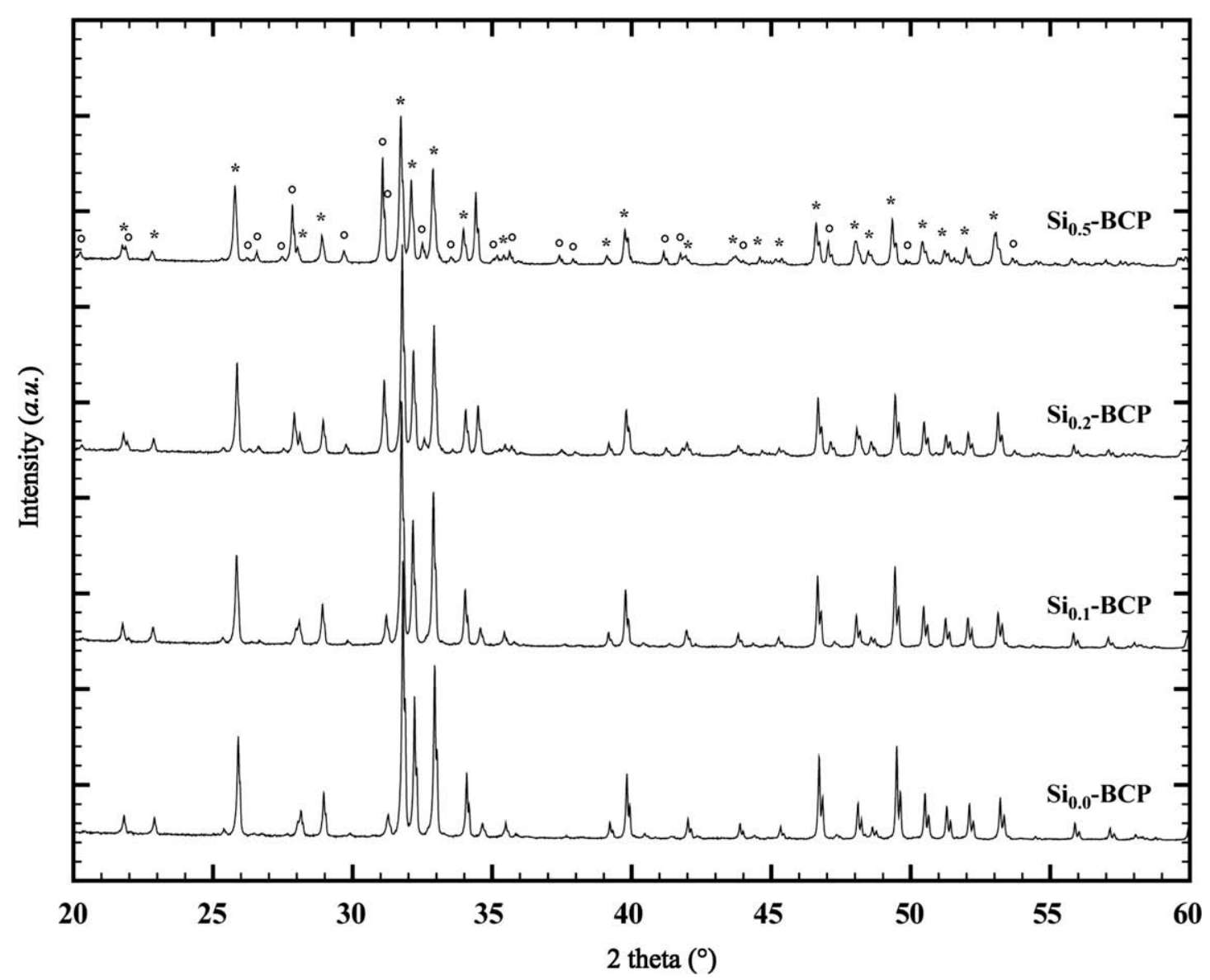

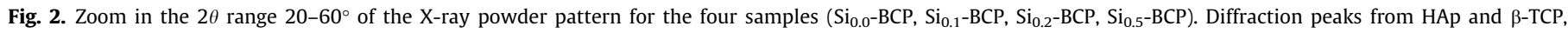
respectively, are indicated by stars and circles, respectively, at the top of the figure.

large increase (up to 2.75 [15]) or to a net decrease (up to 0.83 , this work). Interatomic distances $d_{\mathrm{P}-\mathrm{O}}$ did not correlate with the silicon substitution level either. The mean interatomic distance $\overline{d_{\mathrm{p}-\mathrm{O}}}$ is not sensitive to silicon substitution (Table 3 ). And the tetrahedral elongation index (TEI, here defined by $\left(d_{\mathrm{p}-0}^{\max }-d_{\mathrm{p}-0}^{\min }\right) / \overline{d_{\mathrm{p}-0}}$, where $d_{\mathrm{p}-0}^{\max }$, $d_{\mathrm{P}-\mathrm{O}}^{\mathrm{min}}$ and $\overline{d_{\mathrm{P}-\mathrm{O}}}$ denote the longer, shorter and average $\mathrm{P}-\mathrm{O}$ distances, respectively, in the phosphate tetrahedron) shows a non-monotonous variation with increasing $x$ value (Table 3 ). The variation in TEI (which decreases in the first step, before increasing) is the reverse of the variation in TDI.

\subsection{Estimation of the chemical composition of the Si-substituted HAp phases}

Consideration of electroneutrality combined with the site occupancies of the $\mathrm{Ca}^{2+}, \mathrm{PO}_{4}^{3-}, \mathrm{O}^{2-}$ and $\mathrm{OH}^{-}$ions allows a chemical formula to be proposed for the silicon-substituted HAp phases. This calculus matches perfectly well in the case of the silicon-free $\mathrm{Si}_{0.0^{-}}$ $\mathrm{BCP}$, sample for which the refined chemical composition of the HAp phase is $\mathrm{Ca}_{9.89}\left(\mathrm{PO}_{4}\right)_{5.90}\left[(\mathrm{OH})_{1.88} \mathrm{O}_{0.10} \square_{0.02}\right]$ ]; with $\square$ corresponding to oxygen vacancy (Table 4 ). The refined anionic charges (19.78 negative charges by considering $5.90 \mathrm{PO}_{4}^{3-}+1.88 \mathrm{OH}^{-}+$ $0.100^{2-}$ ) compensate exactly the refined cationic charges (19.78 positive charges by considering $\left.9.89 \mathrm{Ca}^{2+}\right)$. When this calculation was applied to Si-substituted samples, an excess positive charge was systematically obtained. The amount of inserted silicate was then calculated by considering the non-isocharge substitution of $\mathrm{SiO}_{4}^{4-}$ for $\mathrm{PO}_{4}^{3-}$. Results of such estimated chemical composition of HAp are given in Table 4. No $\mathrm{HPO}_{4}^{2-}$ were taken into consideration here, as the $\mathrm{H} 2$ site, identified by Arcos et al. for Si-substituted HAp sample synthesized by the ceramic route [30], was systematically found to be empty in the samples (Table 3). The calculated amount of silicate inserted in HAp was found to increase with the $x$ nominal value. Nevertheless, about one-third of the silicon determined by chemical analyses (Table 1) was found to be inserted in the HAp phase only: HAp from the $\mathrm{Si}_{0.1}$-BCP sample contains 0.03 mol. silicate against 0.09 found by chemical analysis ( 33 mol.\%), HAp from $\mathrm{Si}_{0.2}$-BCP sample contains $0.06 \mathrm{~mol}$. silicate against 0.15 found by chemical analysis (40 mol.\%), and HAp from $\mathrm{Si}_{0.5}$-BCP sample contains $0.16 \mathrm{~mol}$. silicate against 0.39 found by chemical analysis ( $41 \mathrm{~mol} . \%$ ). The other two-thirds of the silicon atoms should be inserted in $\beta$-TCP phase, in agreement with a previous observation made on variation in the unit cell volumes of both HAp and $\beta$-TCP phases. The HAp phase from the BCP samples is slightly calcium and phosphate deficient and contains small amounts of vacancies in the hydroxyl site. The whole calcium deficiency of HAp was localized in the Ca1 site, i.e., the calcium site that is not connected to the hydroxyl site (see Fig. 4 in Ref. [36]). The deficit of charge is imbalanced by the $\mathrm{OH}^{-} / \mathrm{O}^{2-}$ ratio. When introducing the silicate anion into the HAp structure, the deficiency of calcium decreases, hydroxyl vacancies increase, and the $\mathrm{OH}^{-} / \mathrm{O}^{2-}$ ratio decreases (from 18.8 for $\mathrm{Si}_{0.0}-\mathrm{BCP}$ to 10.2 for $\mathrm{Si}_{0.5}-\mathrm{BCP}$, owing to a continuous decrease in the amount of $\mathrm{OH}^{-}$combined with an increase in the amount of $\mathrm{O}^{2-}$ ). The two following mechanisms were proposed to explain the silicate substitution for phosphate into HAp [15,30]:

$\mathrm{PO}_{4}^{3-}+\mathrm{OH}^{-} \leftrightarrow \mathrm{SiO}_{4}^{4-}+\square_{\mathrm{OH}}$

( $\square_{\mathrm{OH}}$ indicates a vacancy in the hydroxyl site)

$\mathrm{PO}_{4}^{3-}+\mathrm{O}^{2-} \leftrightarrow \mathrm{SiO}_{4}^{4-}+\mathrm{OH}^{-}$ 

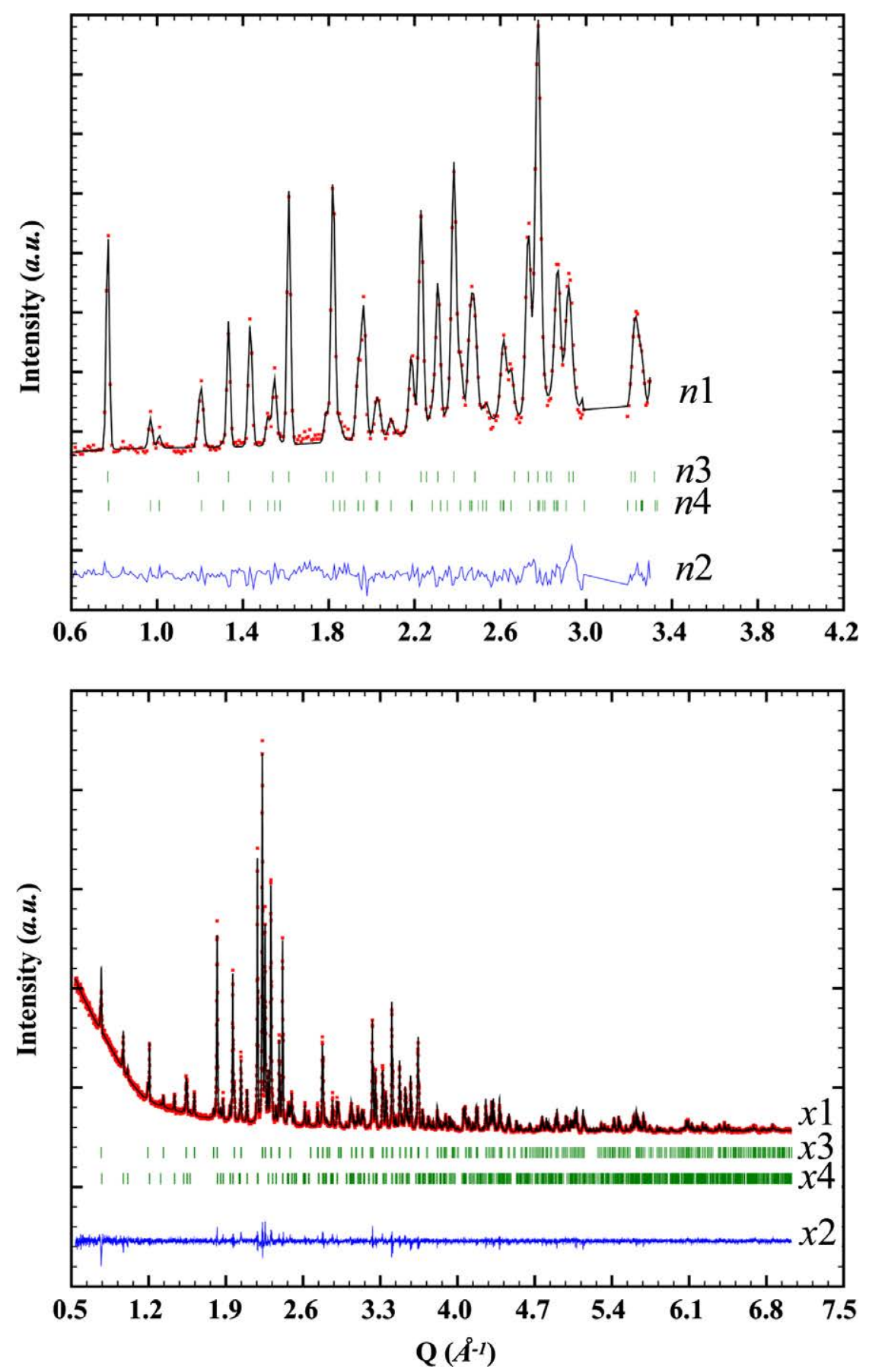

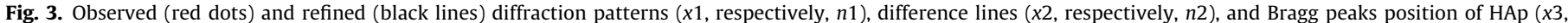
respectively, $n 3)$ and $\beta$-TCP $(x 4$, respectively, $n 4)$ of joint Rietveld refinement of $\mathrm{X}$-ray data (bottom), respectively, neutron data (top) for $\mathrm{Si}_{0.5}$ - $\mathrm{BCP}$ sample.

Table 2

Joint Rietveld refinement results: quantitative analyses, lattice parameters, unit cell volumes and average apparent size; standard deviations are indicated in brackets.

\begin{tabular}{|c|c|c|c|c|c|c|c|c|c|c|}
\hline \multirow[t]{2}{*}{ Sample } & \multicolumn{5}{|c|}{ HAp phase } & \multicolumn{5}{|c|}{$\beta$-TCP phase } \\
\hline & wt.\% & $a(\AA)$ & $c(\AA)$ & $V\left(\AA^{3}\right)$ & Lc $(\AA)^{\mathrm{a}}$ & wt.\% & $a(\AA)$ & $c(\AA)$ & $V\left(\AA^{3}\right)$ & $L c(\AA)^{\mathrm{a}}$ \\
\hline $\mathrm{Si}_{0.0}-\mathrm{BCP}$ & 91 & $9.42481(6)$ & $6.88600(5)$ & $529.715(6)$ & 2200 & 9 & $10.3573(3)$ & $37.172(2)$ & $3453.4(2)$ & 1800 \\
\hline $\mathrm{Si}_{0.1}-\mathrm{BCP}$ & 89 & $9.42387(6)$ & $6.88887(5)$ & $529.830(7)$ & 2100 & 11 & $10.3655(2)$ & $37.182(1)$ & $3459.7(2)$ & 1800 \\
\hline $\mathrm{Si}_{0.2}-\mathrm{BCP}$ & 72 & $9.4264(1)$ & $6.8927(1)$ & $530.41(1)$ & 1900 & 28 & $10.3988(2)$ & $37.315(1)$ & $3494.4(1)$ & 1900 \\
\hline $\mathrm{Si}_{0.5}-\mathrm{BCP}$ & 60 & $9.4283(1)$ & $6.9062(1)$ & $531.66(1)$ & 1250 & 40 & $10.4122(2)$ & $37.3276(8)$ & $3504.7(1)$ & 2050 \\
\hline
\end{tabular}

${ }^{\text {a }}$ Average coherent domain size determined by the diffraction line broadening in course of the Rietveld analyses. 


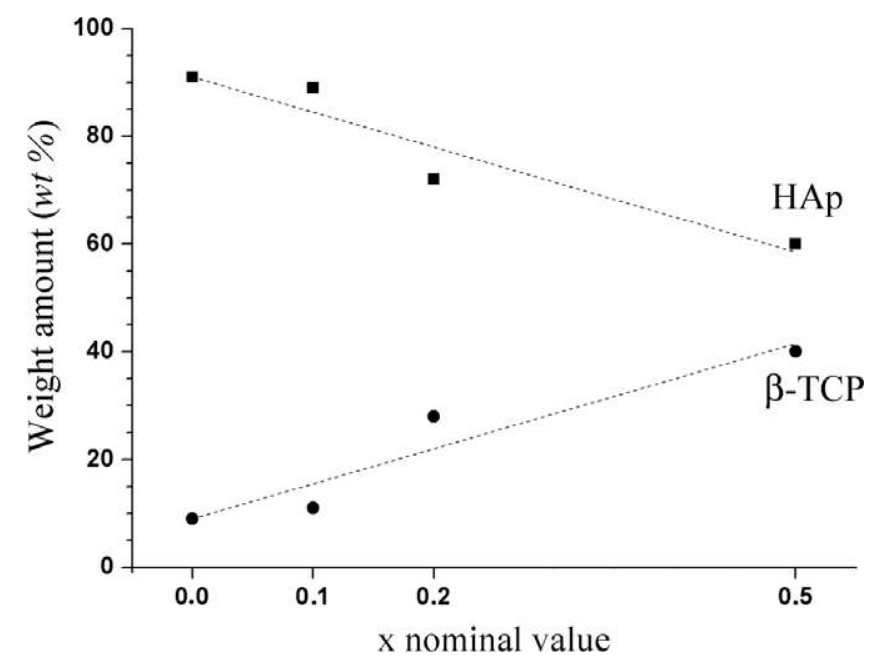

Fig. 4. Quantitative phase Rietveld analyses results: squares and circles indicate, respectively, the weight amounts of HAp and $\beta$-TCP phases. Dotted linear lines are just guides for the eyes.

Mechanism (1) induces a decrease in the $\mathrm{OH}^{-}$amount and an increase in the vacancy in the hydroxyl site in agreement with experimental observations. Mechanism (2) should lead to a decrease in the amount of $\mathrm{O}^{2-}$ and an increase in the amount of $\mathrm{OH}^{-}$, contrary to experimental observations. Another mechanism, implying a calcium cation, should be considered to take into account the increase in the amount of $\mathrm{Ca}^{2+}$ :

$\square_{\mathrm{Ca}}+2 \mathrm{PO}_{4}^{3-} \leftrightarrow \mathrm{Ca}^{2+}+2 \mathrm{SiO}_{4}^{4-}$

( $\square_{\mathrm{Ca}}$ indicates a vacancy in the calcium Ca1 site)

Mechanism (3) explains the increase in the amount of $\mathrm{Ca}^{2+}$ when silicon is inserted, but not the increase in $\mathrm{O}^{2-}$. Then the $\mathrm{OH}^{-} / \mathrm{O}^{2-}$ couple should be considered in this mechanism as follows:

$\square_{\mathrm{Ca}}+\mathrm{PO}_{4}^{3-}+\mathrm{OH}^{-} \leftrightarrow \mathrm{Ca}^{2+}+\mathrm{SiO}_{4}^{4-}+\mathrm{O}^{2-}$

Mechanisms (1) and (4) explain all the observed variations: substitution of silicate for phosphate is accompanied by an increase in the amounts of $\mathrm{Ca}^{2+}, \mathrm{O}^{2-}$ and vacancies in the hydroxyl site $\left(\square_{\mathrm{OH}}\right)$, and a decrease in the amount of $\mathrm{OH}^{-}$in order to ensure charge imbalance.

\subsection{NMR characterization}

The ${ }^{31} \mathrm{P}$ MAS-NMR spectra of $\mathrm{Si}_{0.0}-\mathrm{BCP}, \mathrm{Si}_{0.2}-\mathrm{BCP}$ and $\mathrm{Si}_{0.5}-\mathrm{BCP}$ (Fig. 7a) presents one main peak at 2.7, 2.8 and $3.0 \mathrm{ppm}$, respectively, and two broader signals at $\sim 0$ and $\sim 5$ ppm whose intensities increase with $\mathrm{Si}$ content. The component $\sim 0 \mathrm{ppm}$ disappears when the ${ }^{31} \mathrm{P}$ spectrum is recorded with ${ }^{1} \mathrm{H}-{ }^{31} \mathrm{P} C \mathrm{CP}$ transfer (Fig. 8), indicating that it corresponds to ${ }^{31} \mathrm{P}$ sites far from ${ }^{1} \mathrm{H}$ sites. The main peak at $\sim 3 \mathrm{ppm}$ remains under $\mathrm{CP}$ conditions, as well as a shoulder at $\sim 5 \mathrm{ppm}$, which suggests the presence of ${ }^{1} \mathrm{H}$ sites in the vicinity of the associated ${ }^{31} \mathrm{P}$ sites. Indeed, the presence of signals at 0 and $3 \mathrm{ppm}$ are in agreement with the presence of the two phases detected by XRD, $\beta$-TCP and HAp. HAp is characterized by one single $\mathrm{P}$ site, and ${ }^{31} \mathrm{P}$ chemical shift values for stoichiometric $\mathrm{HAp}\left(\mathrm{Ca}_{10}\left(\mathrm{PO}_{4}\right)_{6}(\mathrm{OH})_{2}\right)$, deficient $\mathrm{HAp}\left(\mathrm{Ca}_{9} \mathrm{HPO}_{4}\left(\mathrm{PO}_{4}\right)_{5} \mathrm{OH}\right)$ and poorly crystallized HAp were reported to be $2.9,3.0$ and $3.3 \mathrm{ppm}$, respectively, with the corresponding line width of 36, 66 and $107 \mathrm{~Hz}$ (under MAS at $5 \mathrm{kHz}$ and high power proton decoupling) [43]. $\beta$-TCP is instead characterized by three distinct crystallographic P sites. However, since one Ca site close to two of the three $P$ sites has a partial occupancy factor of 0.5 , five NMR signals are expected, and the published ${ }^{31} \mathrm{P}$ NMR spectrum of $\beta$-TCP was so
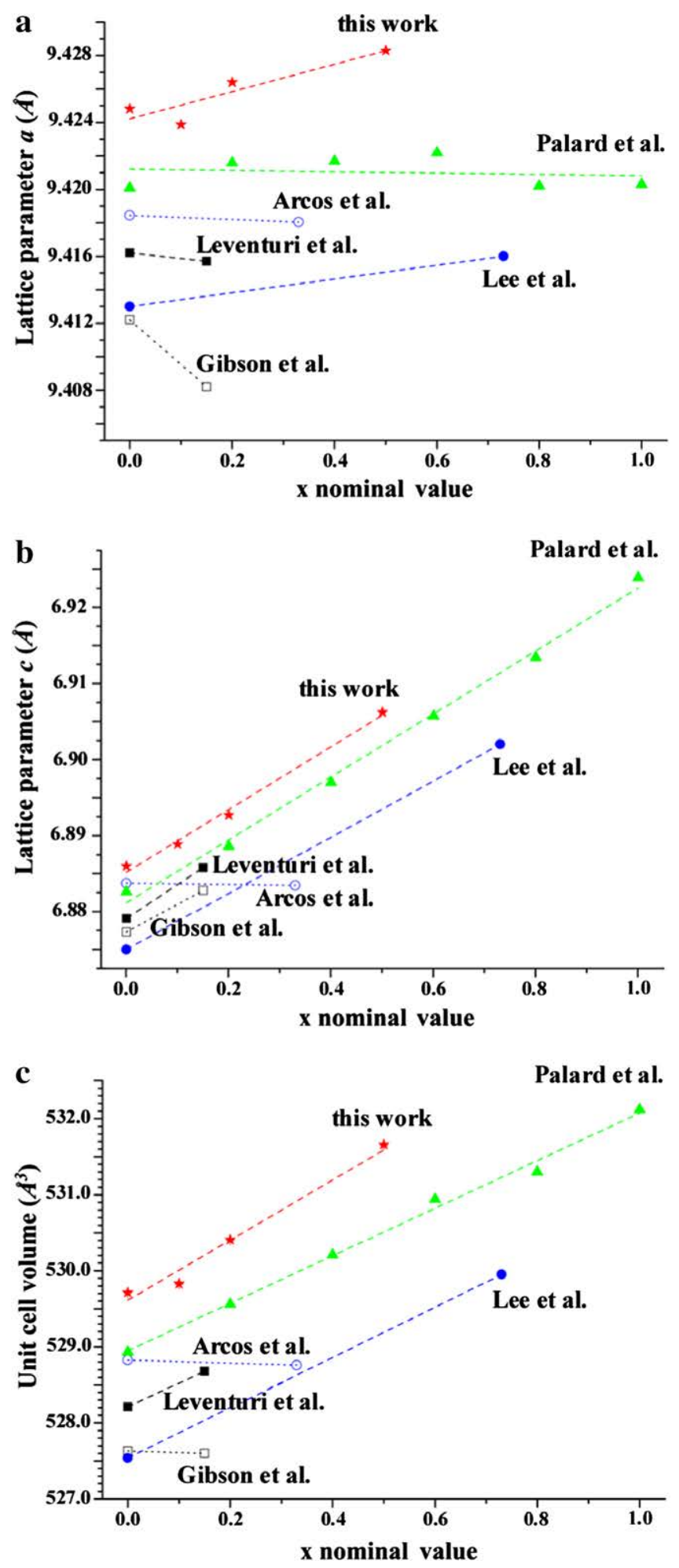

Fig. 5. Variation of the lattice parameters $a$ (a) and $c$ (b) and of the unit cell volume (c) for the HAp phase as a function of the $x$ nominal value from this work and the previously reported data in the literature. Dashed lines are linear fittings of the various data.

far satisfactorily simulated with five resonance peaks $[44,45]$. The most intense peak $\sim 0$ ppm is clearly observed in Fig. 7a. Its intensity increases with the Si content, in agreement with the $\beta$-TCP content calculated from Rietveld refinements. Also the peak at $\sim 3 \mathrm{ppm}$ assigned to HAp broadens (from $\mathrm{LWHM}=45 \mathrm{~Hz}$ in $\mathrm{Si}_{0.0^{-}}$ BCP, $70 \mathrm{~Hz}$ in $\mathrm{Si}_{0.2}$-BCP to $165 \mathrm{~Hz}$ in $\mathrm{Si}_{0.5}-\mathrm{BCP}$ ). 


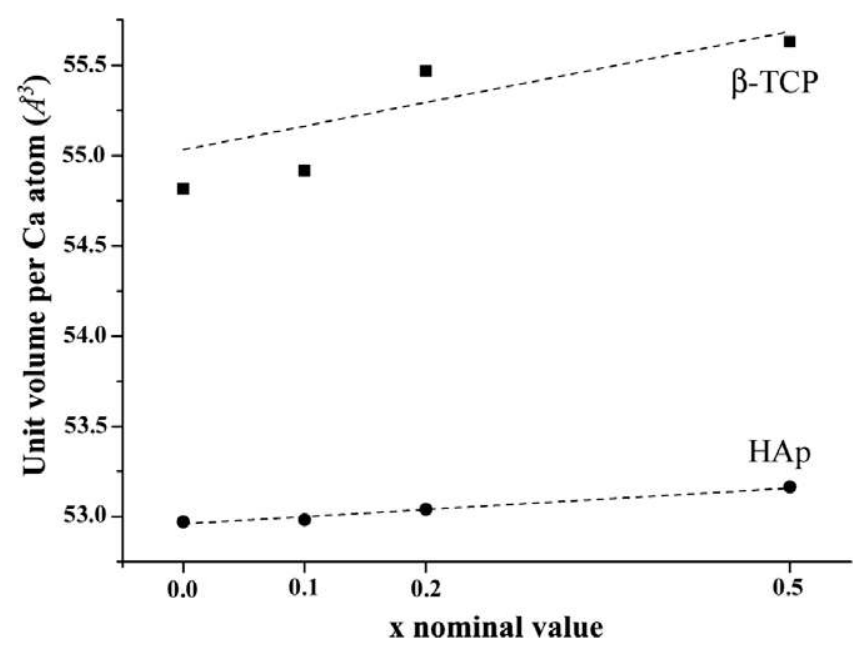

Fig. 6. Variation of unit volume per Ca atom for both HAp and $\beta$-TCP phases as a function of the $x$ nominal value. Dashed lines are linear fittings.
The ${ }^{1} \mathrm{H}$ MAS-NMR spectra of $\mathrm{Si}_{0.0}-\mathrm{BCP}, \mathrm{Si}_{0.2}-\mathrm{BCP}$ and $\mathrm{Si}_{0.5}-\mathrm{BCP}$ (Fig. 7b) are dominated by one peak at $0 \mathrm{ppm}$, characteristic of $\mathrm{OH}$ groups in an apatite structure, and one small component at $5.2 \mathrm{ppm}$, only present in $\mathrm{Si}_{0.2}-\mathrm{BCP}$ and $\mathrm{Si}_{0.5}-\mathrm{BCP}$, which accounts for $8 \%$ and $18 \%$ of the total ${ }^{1} \mathrm{H}$ signal intensity, respectively. As observed for the ${ }^{31} \mathrm{P}$ signal of the apatite structure at $\sim 3 \mathrm{ppm}$, the ${ }^{1} \mathrm{H}$ signal broadens with the $\mathrm{Si}$ content from $\mathrm{LWHM}=115 \mathrm{~Hz}$ in $\mathrm{Si}_{0.0^{-}}$ BCP, $165 \mathrm{~Hz}$ in $\mathrm{Si}_{0.2}$-BCP to $245 \mathrm{~Hz}$ in $\mathrm{Si}_{0.5}$-BCP. The concomitant broadening of the ${ }^{31} \mathrm{P}$ and ${ }^{1} \mathrm{H}$ resonances due to HAp with the Si content suggests that Si atoms are inserted in the HAp framework (as will be established later with the ${ }^{29} \mathrm{Si}$ NMR experiments), which causes a broadening of the ${ }^{31} \mathrm{P}$ and ${ }^{1} \mathrm{H}$ site distributions.

Two-dimensional ${ }^{1} \mathrm{H}-{ }^{31} \mathrm{P}$ HETCOR spectra recorded on $\mathrm{Si}_{0.2}-\mathrm{BCP}$ and $\mathrm{Si}_{0.5}$-BCP (Fig. 9) show an expected correlation between the ${ }^{31} \mathrm{P}$ signal at $\sim 3 \mathrm{ppm}$ and the ${ }^{1} \mathrm{H}$ signal at $\sim 0 \mathrm{ppm}$ characteristic of the apatite structure. More interestingly, it shows that the ${ }^{1} \mathrm{H}$ signal at $5.2 \mathrm{ppm}$ correlates mainly with a ${ }^{31} \mathrm{P}$ signal at $\sim 5 \mathrm{ppm}$ and to a minor extent with the main ${ }^{31} \mathrm{P}$ signal at $\sim 3 \mathrm{ppm}$. The presence of this last correlation shows that these protons, which are present only in the Si-containing samples, are part of the apatite phase. Comparison of the ${ }^{31} \mathrm{P}$ magnetization build-up of the

Table 3

Joint Rietveld refinement results of HAp phase.

\begin{tabular}{|c|c|c|c|c|c|}
\hline Sample & & $\mathrm{Si}_{0.0}-\mathrm{BCP}$ & $\mathrm{Si}_{0.1}-\mathrm{BCP}$ & $\mathrm{Si}_{0.2}-\mathrm{BCP}$ & $\mathrm{Si}_{0.5}-\mathrm{BCP}$ \\
\hline Ca1 (4f) & $\begin{array}{l}Z \\
\mathrm{~B}_{\mathrm{Ca} 1}\left(\AA^{2}\right) \\
\text { Occ. }\end{array}$ & $\begin{array}{l}0.0025(7) \\
2.02(4) \\
0.973(3)\end{array}$ & $\begin{array}{l}0.0020(7) \\
2.10(4) \\
0.970(3)\end{array}$ & $\begin{array}{l}0.002(1) \\
2.31(8) \\
0.976(7)\end{array}$ & $\begin{array}{l}0.001(1) \\
2.53(8) \\
0.985(9)\end{array}$ \\
\hline $\mathrm{Ca} 2(6 h)$ & $\begin{array}{l}x \\
y \\
\mathrm{~B}_{\mathrm{Ca} 2}\left(\AA^{2}\right) \\
\text { Occ. }\end{array}$ & $\begin{array}{l}0.2456(4) \\
0.9925(4) \\
=\mathrm{B}_{\mathrm{Ca} 1} \\
1(-)\end{array}$ & $\begin{array}{l}0.2462(4) \\
0.9924(4) \\
=\mathrm{B}_{\mathrm{Ca} 1} \\
1(-)\end{array}$ & $\begin{array}{l}0.2460(6) \\
0.9916(7) \\
=\mathrm{B}_{\mathrm{Ca} 1} \\
1(-)\end{array}$ & $\begin{array}{l}0.2457(7) \\
0.9907(8) \\
=B_{\mathrm{Ca} 1} \\
1(-)\end{array}$ \\
\hline P1 (6h) & $\begin{array}{l}x \\
y \\
\mathrm{~B}_{\mathrm{P} 1}\left(\AA^{2}\right) \\
\text { Occ. }\end{array}$ & $\begin{array}{l}0.3969(5) \\
0.3675(5) \\
2.25(8) \\
0.983(4)\end{array}$ & $\begin{array}{l}0.3970(4) \\
0.3676(4) \\
2.23(8) \\
0.980(4)\end{array}$ & $\begin{array}{l}0.3963(8) \\
0.3651(8) \\
2.5(1) \\
0.983(7)\end{array}$ & $\begin{array}{l}0.3960(9) \\
0.3658(9) \\
2.8(1) \\
0.987(9)\end{array}$ \\
\hline $01(6 h)$ & $\begin{array}{l}x \\
y \\
\mathrm{~B}_{\mathrm{O} 1}\left(\AA^{2}\right) \\
\text { Occ. }\end{array}$ & $\begin{array}{l}0.3269(8) \\
0.4854(8) \\
2.32(9) \\
0.985(6)\end{array}$ & $\begin{array}{l}0.3271(8) \\
0.4847(8) \\
2.41(9) \\
0.980(4)\end{array}$ & $\begin{array}{l}0.325(1) \\
0.488(1) \\
2.2(2) \\
0.983(9)\end{array}$ & $\begin{array}{l}0.324(1) \\
0.486(1) \\
2.2(2) \\
0.987(9)\end{array}$ \\
\hline $\mathrm{O} 2(6 h)$ & $\begin{array}{l}x \\
y \\
\mathrm{~B}_{\mathrm{O} 2}\left(\AA^{2}\right) \\
\text { Occ. }\end{array}$ & $\begin{array}{l}0.5880(8) \\
0.4664(9) \\
=\mathrm{B}_{\mathrm{O} 1} \\
0.985(6)\end{array}$ & $\begin{array}{l}0.5871(8) \\
0.4653(9) \\
=\mathrm{B}_{\mathrm{O} 1} \\
0.980(4)\end{array}$ & $\begin{array}{l}0.586(1) \\
0.466(1) \\
=\mathrm{B}_{\mathrm{O} 1} \\
0.983(9)\end{array}$ & $\begin{array}{l}0.585(1) \\
0.468(1) \\
=\mathrm{B}_{\mathrm{O} 1} \\
0.987(9)\end{array}$ \\
\hline $\mathrm{H} 2(6 h)$ & $\begin{array}{l}x \\
y \\
\mathrm{~B}_{\mathrm{H} 2}\left(\AA^{2}\right) \\
\text { Occ. }\end{array}$ & $\begin{array}{l}0.4746(-) \\
0.1666(-) \\
=1.2 \times \mathrm{B}_{\mathrm{O} 1} \\
0.008(6)\end{array}$ & $\begin{array}{l}0.4746(-) \\
0.1666(-) \\
=1.2 \times \mathrm{B}_{\mathrm{O} 1} \\
0.012(8)\end{array}$ & $\begin{array}{l}0.4746(-) \\
0.1666(-) \\
=1.2 \times \mathrm{B}_{01} \\
0.01(1)\end{array}$ & $\begin{array}{l}0.4746(-) \\
0.1666(-) \\
=1.2 \times \mathrm{B}_{01} \\
0.01(1)\end{array}$ \\
\hline O3 (12i) & $\begin{array}{l}x \\
y \\
z \\
\mathrm{~B}_{\mathrm{O} 3}\left(\AA^{2}\right) \\
\text { Осc. }\end{array}$ & $\begin{array}{l}0.3401(6) \\
0.2562(6) \\
0.0691(6) \\
=B_{01} \\
0.985(6)\end{array}$ & $\begin{array}{l}0.3401(6) \\
0.2562(6) \\
0.0695(6) \\
=\mathrm{B}_{\mathrm{O} 1} \\
0.980(4)\end{array}$ & $\begin{array}{l}0.341(1) \\
0.258(1) \\
0.069(1) \\
=B_{\mathrm{O} 1} \\
0.983(9)\end{array}$ & $\begin{array}{l}0.342(1) \\
0.258(1) \\
0.070(1) \\
=\mathrm{B}_{\mathrm{O} 1} \\
0.987(9)\end{array}$ \\
\hline O4 (4e) & $\begin{array}{l}z \\
\mathrm{~B}_{\mathrm{O} 4}\left(\AA^{2}\right) \\
\text { Occ. }\end{array}$ & $\begin{array}{l}0.202(3) \\
=\mathrm{B}_{\mathrm{O} 1} \\
0.495(5)\end{array}$ & $\begin{array}{l}0.203(2) \\
=\mathrm{B}_{\mathrm{O} 1} \\
0.490(6)\end{array}$ & $\begin{array}{l}0.199(4) \\
=\mathrm{B}_{\mathrm{O} 1} \\
0.48(1)\end{array}$ & $\begin{array}{l}0.196(4) \\
=\mathrm{B}_{\mathrm{O} 1} \\
0.45(1)\end{array}$ \\
\hline H4 (4e) & $\begin{array}{l}z \\
\mathrm{~B}_{\mathrm{H} 4}\left(\AA^{2}\right) \\
\text { Occ. }\end{array}$ & $\begin{array}{l}0.077(7) \\
=1.2 \times \mathrm{B}_{\mathrm{O} 1} \\
0.470(8)\end{array}$ & $\begin{array}{l}0.084(8) \\
=1.2 \times \mathrm{B}_{\mathrm{O} 1} \\
0.458(9)\end{array}$ & $\begin{array}{l}0.09(1) \\
=1.2 \times \mathrm{B}_{\mathrm{O} 1} \\
0.45(2)\end{array}$ & $\begin{array}{l}0.08(1) \\
=1.2 \times \mathrm{B}_{\mathrm{O} 1} \\
0.41(2)\end{array}$ \\
\hline$\frac{d_{\mathrm{O} 4-\mathrm{H} 4}(\AA)}{d_{\mathrm{p}-0}(\AA)^{a}}$ & & $\begin{array}{l}0.86(5) \\
1.548\end{array}$ & $\begin{array}{l}0.82(6) \\
1.543\end{array}$ & $\begin{array}{l}0.8(1) \\
1.548\end{array}$ & $\begin{array}{l}0.79(6) \\
1.543\end{array}$ \\
\hline $\begin{array}{l}\mathrm{TEI}^{\mathrm{a}} \\
\mathrm{TDI}^{\mathrm{a}}\end{array}$ & & $\begin{array}{l}0.013 \\
1.47\end{array}$ & $\begin{array}{l}0.006 \\
1.54\end{array}$ & $\begin{array}{l}0.052 \\
0.83\end{array}$ & $\begin{array}{l}0.045 \\
0.97\end{array}$ \\
\hline$\chi^{2 b}$ & & $2.48,6.30$ & $2.23,3.91$ & $2.53,7.84$ & $2.09,6.15$ \\
\hline
\end{tabular}

TEI and TDI formulae are given in the text. $\overline{d_{\mathrm{P}-0}}$ is the average interatomic distance of the phosphate tetrahedron.

b Rietveld refinement accuracy for X-ray and neutron patterns, respectively. 
Table 4

Proposed chemical formulae for HAp phases.

\begin{tabular}{|c|c|c|c|c|}
\hline Sample & \multicolumn{2}{|c|}{ Refined atomic amount } & Charge imbalance & Calculated chemical composition \\
\hline $\mathrm{Si}_{0.0}-\mathrm{BCP}$ & $\begin{array}{l}\mathrm{Ca}^{2+} \\
\mathrm{PO}_{4}^{3-} \\
\mathrm{OH}^{-} \\
\mathrm{O}^{2-}\end{array}$ & $\begin{array}{l}9.89 \\
5.90 \\
1.88 \\
0.10\end{array}$ & $\begin{array}{l}19.78^{+} \\
19.78^{-} \rightarrow 0.00 \mathrm{SiO}_{4}^{4-}\end{array}$ & $\mathrm{Ca}_{9.89}\left(\mathrm{PO}_{4}\right)_{5.90}\left[(\mathrm{OH})_{1.88} \mathrm{O}_{0.10} \square_{0.02}\right]$ \\
\hline $\mathrm{Si}_{0.1}-\mathrm{BCP}$ & $\begin{array}{l}\mathrm{Ca}^{2+} \\
\mathrm{PO}_{4}^{3-} \\
\mathrm{OH}^{-} \\
\mathrm{O}^{2-}\end{array}$ & $\begin{array}{l}9.88 \\
5.88 \\
1.83 \\
0.13\end{array}$ & $\begin{array}{l}19.76^{+} \\
19.73^{-} \rightarrow 0.03 \mathrm{SiO}_{4}^{4-}\end{array}$ & $\mathrm{Ca}_{9.88}\left[\left(\mathrm{PO}_{4}\right)_{5.85}\left(\mathrm{SiO}_{4}\right)_{0.03}\right]\left[(\mathrm{OH})_{1.83} \mathrm{O}_{0.13} \square_{0.04}\right]$ \\
\hline $\mathrm{Si}_{0.2}-\mathrm{BCP}$ & $\begin{array}{l}\mathrm{Ca}^{2+} \\
\mathrm{PO}_{4}^{3-} \\
\mathrm{OH}^{-} \\
\mathrm{O}^{2-}\end{array}$ & $\begin{array}{l}9.90 \\
5.90 \\
1.80 \\
0.12\end{array}$ & $\begin{array}{l}19.80^{+} \\
19.74^{-} \rightarrow 0.06 \mathrm{SiO}_{4}^{4-}\end{array}$ & $\mathrm{Ca}_{9.90}\left[\left(\mathrm{PO}_{4}\right)_{5.84}\left(\mathrm{SiO}_{4}\right)_{0.06}\right]\left[(\mathrm{OH})_{1.80} \mathrm{O}_{0.12} \square_{0.08}\right]$ \\
\hline $\mathrm{Si}_{0.5}-\mathrm{BCP}$ & $\begin{array}{l}\mathrm{Ca}^{2+} \\
\mathrm{PO}_{4}^{3-} \\
\mathrm{OH}^{-} \\
\mathrm{O}^{2-}\end{array}$ & $\begin{array}{l}9.94 \\
5.92 \\
1.64 \\
0.16\end{array}$ & $\begin{array}{l}19.88^{+} \\
19.72^{-} \rightarrow 0.16 \mathrm{SiO}_{4}^{4-}\end{array}$ & $\mathrm{Ca}_{9.94}\left[\left(\mathrm{PO}_{4}\right)_{5.76}\left(\mathrm{SiO}_{4}\right)_{0.16}\right]\left[(\mathrm{OH})_{1.64} \mathrm{O}_{0.16} \square_{0.20}\right]$ \\
\hline
\end{tabular}

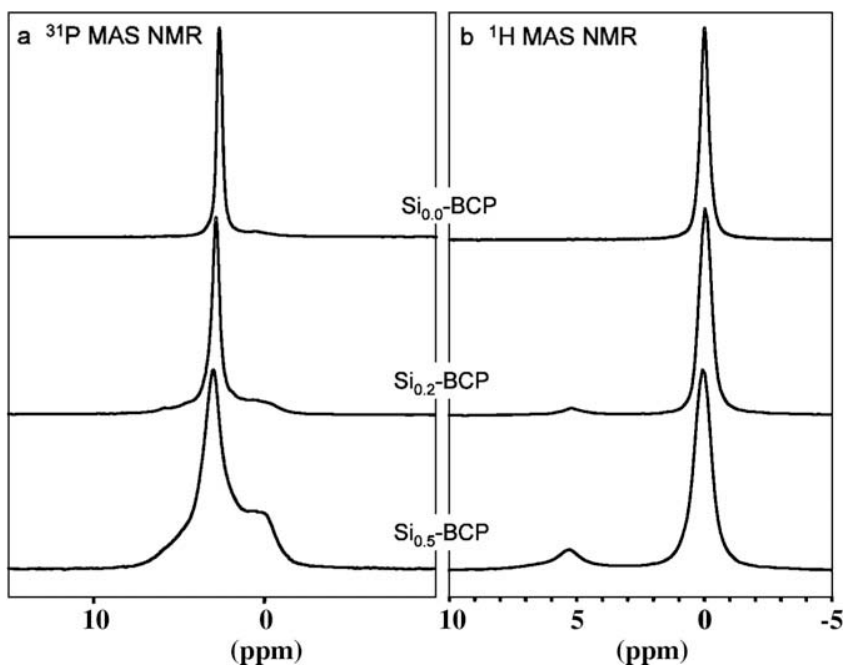

Fig. 7. ${ }^{31} \mathrm{P}(\mathrm{a})$ and ${ }^{1} \mathrm{H}$ (b) MAS-NMR spectra of the $\mathrm{Si}_{0.0}-\mathrm{BCP}, \mathrm{Si}_{0.2}-\mathrm{BCP}$ and $\mathrm{Si}_{0.5}-\mathrm{BCP}$ samples.

two signals at 2.9 and $4.6 \mathrm{ppm}$ in $\mathrm{Si}_{0.5}-\mathrm{BCP}$ during a ${ }^{1} \mathrm{H}-{ }^{31} \mathrm{P} \mathrm{CP}$ transfer suggests closer proximity between ${ }^{31} \mathrm{P}$ and ${ }^{1} \mathrm{H}$ sites for the peak at $4.6 \mathrm{ppm}$ with respect to the main apatite signal at $2.9 \mathrm{ppm}$. This is confirmed by refinements where the distance P1-H4 decreases from $3.80 \AA$ for undoped BCP to $3.76 \AA$ for the Si-substituted sample. However, the build-up is slower than for $\mathrm{POH}$ groups in monetite, $\mathrm{CaHPO}_{4}(\mathrm{P}-\mathrm{H}$ distance $=1.90-2.3 \AA)$. This experiment shows that insertion of $\mathrm{Si}$ atoms in HAp leads to the formation of new $\mathrm{P}$ and $\mathrm{H}$ sites. The ${ }^{1} \mathrm{H}$ chemical shift value, which is very different from that of apatite $\mathrm{OH}$, could suggest that the corresponding $\mathrm{OH}$ groups are engaged in $\mathrm{H}$-bonding. Considering this new experimental observation can allow a more refined description of the Si-substituted HAp. In effect in HAp structure, each hydroxyl $\mathrm{OH}$ is surrounded by three phosphate anions with three distances $\mathrm{H} 4-\mathrm{P} 1$ of $3.85 \AA$, and three distances $\mathrm{H} 4-\mathrm{O} 3$ of $2.89 \AA$ (three distances $04-03$ of $3.03 \AA$ ). Considering the previously described mechanism for substitution of a phosphate anion for a silicate anion, and taking into account the creation of a hydrogen bond between the hydroxyl group (defined by $\mathrm{O} 4$ and $\mathrm{H} 4$ atoms) with oxygen $\mathrm{O} 3$ from the silicate, two $\mathrm{OH}^{-}$are now found engaged in hydrogen bonding per inserted silicate anion. In effect, a phosphate group (and thus also a silicate group) is defined by two oxy-

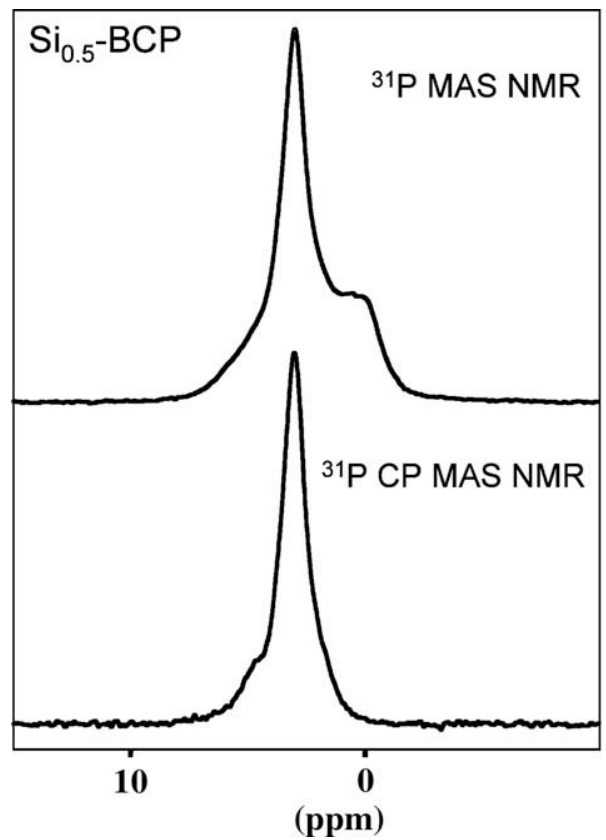

Fig. 8. Comparison between ${ }^{31} \mathrm{P}$ MAS-NMR and CP-MAS-NMR spectra recorded on $\mathrm{Si}_{0.5}$-BCP sample.

gen $\mathrm{O} 3$ (plus 1 oxygen 01 and 1 oxygen 02 ). This situation is depicted in Fig. 10.

Taking into account the formula $\left(\mathrm{Ca}_{9.94}\left[\left(\mathrm{PO}_{4}\right)_{5.76}\left(\mathrm{SiO}_{4}\right)_{0.16}\right][(\mathrm{O}-\right.$ $\left.\mathrm{H})_{1.64} \mathrm{O}_{0.16} \square_{0.20}\right]$ ) derived for $\mathrm{Si}_{0.5}$-BCP in Table 4 , and considering two $\mathrm{OH}^{-}$engaged in hydrogen bonding per silicate, one can refine the formula to $\mathrm{Ca}_{9.94}\left[\left(\mathrm{PO}_{4}\right)_{5.76}\left(\mathrm{SiO}_{4} \cdot(\mathrm{OH})_{2}\right)_{0.16}\right]\left[(\mathrm{OH})_{1.32} \mathrm{O}_{0.16} \square_{0.20}\right]$ introducing two types of $\mathrm{OH}^{-}$groups: 0.32 in the hydrogen bond with silicate, and 1.32 in the normal HAp position. Considering the refined amount of $\mathrm{Si}$, this yields $20 \%$ of $\mathrm{H}$ engaged in hydrogen bonding with silicates, and $80 \%$ in the normal HAp position, in perfect agreement with ${ }^{1} \mathrm{H}$ NMR data (18\%/82\%). For the same considerations for the lower doping level $\mathrm{Si}_{0.2}-\mathrm{BCP}$, the derived formula $\left(\mathrm{Ca}_{9.90}\left[\left(\mathrm{PO}_{4}\right)_{5.84}\left(\mathrm{SiO}_{4}\right)_{0.06}\right]\left[(\mathrm{OH})_{1.80} \mathrm{O}_{0.12} \square_{0.08}\right]\right)$ from Table 4 gives a refined formula $\mathrm{Ca}_{9.90}\left[\left(\mathrm{PO}_{4}\right)_{5.84}\left(\mathrm{SiO}_{4}(\mathrm{OH})_{2}\right)_{0.06}\right]\left[(\mathrm{OH})_{1.68} \mathrm{O}_{0.12} \square_{0.08}\right]$ corresponding to $7 \%$ and $93 \%$, respectively, for protons engaged in hydrogen bonding and normal ones, again in extremely good agreement with NMR data $(8 \% / 92 \%)$. 


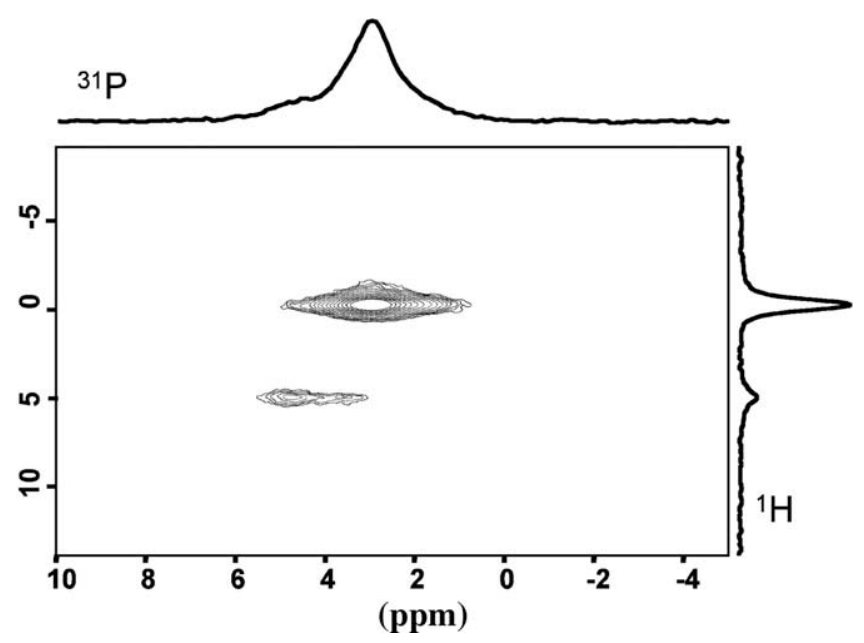

Fig. 9. ${ }^{1} \mathrm{H}^{-31} \mathrm{P}$ HETCOR experiment recorded on the $\mathrm{Si}_{0.5}-\mathrm{BCP}$ sample.
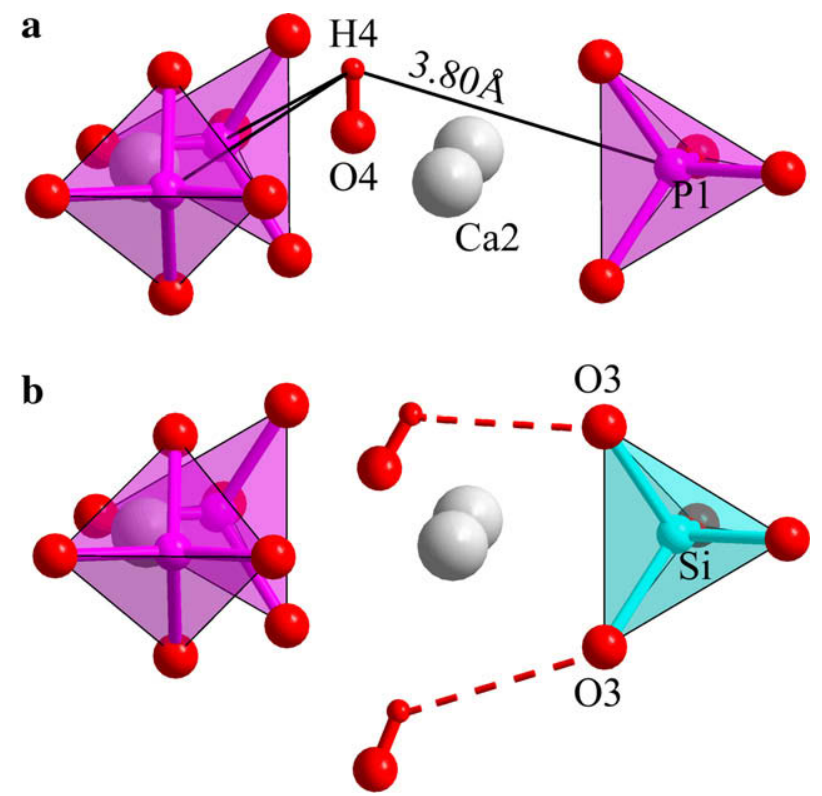

Fig. 10. Representation of the environment of hydroxyl group in HAp structure: as observed in the undoped HAp phase (a) and in the case of silicon substitution involving two hydrogen bonds per silicate anion (b). Grey, pink, light blue, large red and small red spheres correspond, respectively, to calcium, phosphorus, silicon, oxygen and hydrogen atoms. Broken red lines indicate hydrogen bonding.

The ${ }^{29} \mathrm{Si}$ MAS-NMR spectra recorded on $\mathrm{Si}_{0.2}$-BCP (Fig. 11) and $\mathrm{Si}_{0.5}-\mathrm{BCP}$ (not shown here) exhibit three signals at $-78,-73$ and $-69 \mathrm{ppm}$. Such values correspond to $\mathrm{SiO}_{4}^{4-}$ silicate ions $\left(Q_{0}\right)$. The peaks are broader in $\mathrm{Si}_{0.5}$-BCP than in $\mathrm{Si}_{0.2}-\mathrm{BCP}$, a feature already observed for the ${ }^{31} \mathrm{P}$ and ${ }^{1} \mathrm{H}$ resonance lines. No other signals are detected, excluding the presence of condensed silicon species (expected between -85 and $-110 \mathrm{ppm}$ ), which is in agreement with the XRD data showing only the presence of HAp and $\beta$-TCP. In $\mathrm{HAp}, \mathrm{SiO}_{4}^{4-}$ silicate ions will occupy the unique $\mathrm{PO}_{4}^{3-}$ site, and a chemical shift value of $-73 \mathrm{ppm}$ has already been reported [41]. In $\beta$-TCP, the presence of three $\mathrm{PO}_{4}^{3-}$ sites suggests that several ${ }^{29} \mathrm{Si}$ resonances may be expected if silicon atoms are inserted in this phase. Hence, the ${ }^{29} \mathrm{Si}$ MAS-NMR spectra can be interpreted as follows: the main peak at $-73 \mathrm{ppm}$ could be safely assigned to silicate sites in HAp, while the other two peaks at -69 and $-78 \mathrm{ppm}$ could be due to silicate sites in $\beta$-TCP. However, the peak at $-73 \mathrm{ppm}$ accounts for $75 \%$ of the total $\mathrm{Si}$ intensity in both

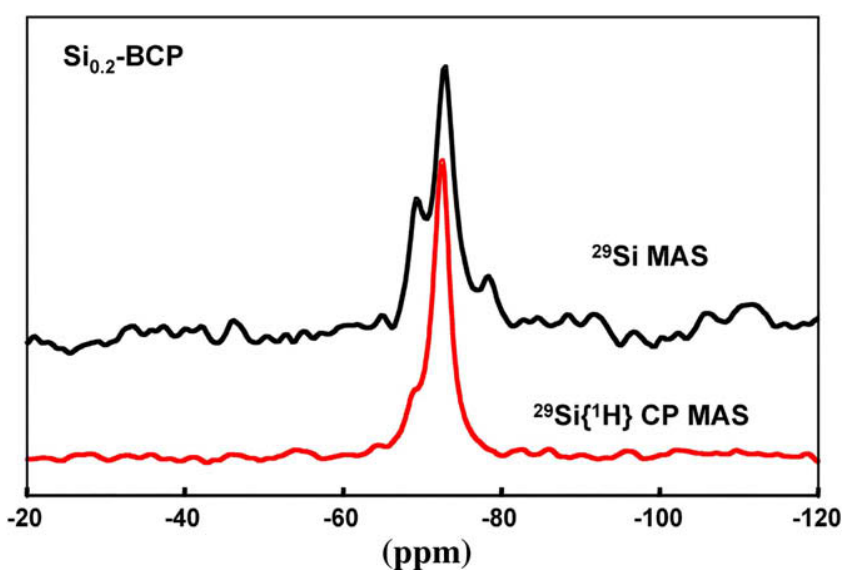

Fig. 11. ${ }^{29} \mathrm{Si}$ and ${ }^{29} \mathrm{Si}\left\{{ }^{1} \mathrm{H}\right\}$ CP-MAS-NMR spectra of $\mathrm{Si}_{0.2}-\mathrm{BCP}$.

samples, which is well above the amount of silicon atoms in HAp calculated from the XRD data: 33 and 40 mol.\% for $\mathrm{Si}_{0.2}$-BCP and $\mathrm{Si}_{0.5}-\mathrm{BCP}$, respectively. One can make the assumption that the peak at $-73 \mathrm{ppm}$ also contains a contribution from silicate ions in $\beta$-TCP. The ${ }^{29} \mathrm{Si}-\left\{{ }^{1} \mathrm{H}\right\}$ CP-MAS experiment recorded for the $\mathrm{Si}_{0.2}$-BCP sample (Fig. 11) confirms the contributions from the two phases with the almost total disappearance of peaks at -69 and $-83 \mathrm{ppm}$ under cross-polarization conditions.

\section{Conclusions}

Silicon-substituted BCP samples were prepared with various amounts of silicon. Joint Rietveld refinements of X-ray and neutron diffraction data allowed the composition of the substituted phases to be determined. Electroneutrality considerations and combination with NMR data allowed refining of the Si-HAp phases formulae introducing two types of hydroxyl anions and vacancies and also to determine the possible substitution mechanisms. The two types of protons as observed in the ${ }^{1} \mathrm{H}$ NMR spectra offer a new structural description of Si-substituted HAp phases.

A review of structural indicators for the substitution level of $\mathrm{Si}$ in HAp clearly shows that parameter $c$ is the best, contrary to what is usually found in the literature.

Altogether, these experimental results offer a very detailed description of silicon substitution in BCP ceramics and should allow a better understanding of the well-documented effect of silicon on the bioactivity of these materials.

\section{Acknowledgements}

This work was supported by ANR under project NANOSHAP (ANR-09-BLAN-0120-03). The staff of the D18 diffractometer at ILL (Grenoble France) are gratefully acknowledged.

\section{References}

[1] Dahl SG, Allain PJ, Mauras Y, Boivin G, Ammann P, Tsouderos Y, et al. Incorporation and distribution of strontium in bone. Bone 2001;28:446.

[2] Lagier R, Baud C-A. Magnesium whitlockite, a calcium phosphate crystal of special interest in pathology. Pathol Res Pract 2003;199:329. 
[3] Lee RS, Kayser MV, Ali SY. Calcium phosphate microcrystal deposition in the human intervertebral disc. J Anat 2006;208(1):13.

[4] Blumenthal NC, Betts F, Posner AS. Effect of carbonate and biological macromolecules on formation and properties of hydroxyapatite. Calcif Tissue Res 1975;18:81.

[5] Bigi A, Cojazzi G, Panzavolta S, Ripamonti A, Roveri N, Romanello M, et al. Chemical and structural characterization of the mineral phase from cortical and trabecular bone. J Inorg Biochem 1997;68:45.

[6] Solomons CC, Neuman WF. On the mechanisms of calcification: the remineralization of dentin. Sobel, A.E.; Rockenmacher, M.; Kramer, B. J Biol Chem 1960;235:2502.

[7] LeGeros RZ. Calcium phosphates in oral biology and medicine. Monogr Oral Sci 1991:15.

[8] de Bruijn JD, Bovell YP, van Blitterswijk CA. Structural arrangements at the interface between plasma-sprayed calcium phosphates and bone. Biomaterials 1994; 15:543.

[9] Gross KA, Berndt CC. Thermal processing of hydroxyapatite for coating production. J Biomed Mater Res 1998;39:580

[10] Kobayashi T, Shingaki S, Nakajima T, Hanada K. Chin augmentation with porous hydroxyapatite blocks. J Long Term Eff Med Implants 1993;3:283.

[11] Bonfield W, Grynpas MD, Tully AE, Bowman J, Abram J. Hydroxyapatite reinforced polyethylene-a mechanically compatible implant material for bone-replacement. Biomaterials 1981;2:185.

[12] Hench LL. Bioceramics-from concept to clinic. J Am Ceram Soc 1991;74:1487.

[13] LeGeros RZ. Effect of carbonate on the lattice parameters of apatite. Nature $1965 ; 206: 403$.

[14] Nelson DGA, Featherstone JDB. Preparation, analysis, and characterization of carbonated apatites. Calcif Tissue Int 1982;34:69.

[15] Gibson IR, Best SM, Bonfield W. Chemical characterization of siliconsubstituted hydroxyapatite. J Biomed Mater Res 1999;44:422.

[16] Patel N, Best SM, Bonfield W, Gibson IR, Hing KA, Damien E, et al. A comparative study on the in vivo behavior of hydroxyapatite and silicon substituted hydroxyapatite granules. J Mater Sci Mater Med 2002;13:1199.

[17] Porter AE, Patel N, Skepper JN, Best SM, Bonfield W. Comparison of in vivo dissolution processes in hydroxyapatite and silicon-substituted hydroxyapatite bioceramics. Biomaterials 2003;24:4609.

[18] Porter AE, Patel N, Skepper JN, Best SM, Bonfield W. Effect of sintered silicatesubstituted hydroxyapatite on remodelling processes at the bone-implant interface. Biomaterials 2004;25:3303.

[19] Hing KA, Revell PA, Smith N, Buckland T. Effect of silicon level on rate, quality and progression of bone healing within silicate-substituted porous hydroxyapatite scaffolds. Biomaterials 2006;27:5014.

[20] Pietak AM, Reid JW, Stott MJ, Sayer M. Silicon substitution in the calcium phosphate bioceramics. Biomaterials 2007;28:4023.

[21] Carlisle EM. Silicon. A possible factor in bone calcification. Science 1970;167:179.

[22] Carlisle EM. Silicon-a requirement in bone-formation independent of vitamin-d1. Calcif Tissue Int 1981;33:27.

[23] Schwarz K, Milne DB. Growth-promoting effects of silicon in rats. Nature 1972;239:333.

[24] Bohner M. Silicon-substituted calcium phosphates-a critical view. Biomaterials 2009;5(9):6403.

[25] Schwartz C, Liss P, Jacquemaire B, Lecestre P, Frayssinet P. Biphasic synthetic bone substitute use in orthopaedic and trauma surgery: clinical, radiological and histological results. J Mater Sci Mater Med 1999;10:821.
[26] LeGeros RZ, Lin S, Rohanizadeh R, Mijares D, LeGeros JP. Biphasic calcium phosphate bioceramics: preparation, properties and applications. J Mater Sci Mater Med 2003;14:201.

[27] Livingston Arinzeh T, Tran T, McAlary J, Daculsi G. A comparative study of biphasic calcium phosphate ceramics for human mesenchymal stem-cellinduced bone formation. Biomaterials 2005;26:3631.

[28] Bouler JM, Trecant M, Delecrin J, Royer J, Passuti N, Daculsi G. Macroporous biphasic calcium phosphate ceramics: influence of five synthesis parameters on compressive strength. J Biomed Mater Res 1996;32:603.

[29] Gomes S, Renaudin G, Jallot E, Nedelec J-M. Structural characterization and biological fluid interaction of sol-gel-derived Mg-substituted biphasic calcium phosphate ceramics. Appl Mater Interfaces 2009;1:505.

[30] Arcos D, Rodriguez-Carvajal J, Vallet-Regi M. The effect of the silicon incorporation on the hydroxylapatite structure. A neutron diffraction study. Solid State Sci 2004;6:987.

[31] Balas F, Pérez-Pariente J, Vallet-Regi M. In vitro bioactivity of siliconsubstituted hydroxyapatites. J Biomed Mater Res 2003;66A:364.

[32] Vallet-Regi M, Arcos D. Silicon substituted hydroxyapatites. A method to upgrade calcium phosphate based implants. J Mater Chem 2005;15:1509.

[33] Rodriguez-Carvajal J. PROGRAM FullProf.2k - version 3.20, Laboratoire Léon Brillouin (CEA-CNRS), France; 2005 (FullProf.2k manual available on http:// www-llb.cea.fr/fullweb/fp2k/fp2k_divers.htm). See also Rodriguez-Carvajal J, Roisnel T. EPDIC-8, 23-26 May 2002. Trans. Tech. Publication Ltd.: Uppsala, Sweden. Mater Sci Forum 2004;123:443.

[34] Rodriguez-Lorenzo LM, Hart JN, Gross KA. Structural and chemical analysis of well-crystallized hydroxyfluorapatites. J Phys Chem B 2003;107:8316.

[35] Yashima M, Sakai A, Kamiyama T, Hoshikawa A. Crystal structure analysis of beta-tricalcium phosphate $\mathrm{Ca}-{ }_{3}\left(\mathrm{PO}_{4}\right)_{(2)}$ by neutron powder diffraction. J Solid State Chem 2003;175:272.

[36] Renaudin G, Laquerrière P, Filinchuk Y, Jallot E, Nedelec J-M. Structural characterization of sol-gel derived Sr-substituted calcium phosphates with anti-osteoporotic and anti-inflammatory properties. J Mater Chem 2008; $18: 3593$.

[37] Leventouri Th, Bunaciu CE, Perdikatsis V. Neutron powder diffraction studies of silicon-substituted hydroxyapatite. Biomaterials 2003;24:4205.

[38] Lee YJ, Kim YH, Kim SR, Jung SJ, Riu DH, Song H, et al. Study on the sinterability of silicon substituted hydroxyapatite. J Korean Ceram Soc 2003;40:1096.

[39] Palard M, Champion E, Foucaud S. Synthesis of silicated hydroxyapatite $\mathrm{Ca}_{-10}\left(\mathrm{PO}_{4}\right)\left({ }_{6-x}\right)\left(\mathrm{SiO}_{4}\right)_{(x)}(\mathrm{OH})_{(2-x)}$. J Solid State Chem 2008;181:1950.

[40] Renaudin G, Jallot E, Nedelec J-M. Effect of strontium substitution on the composition and microstructure of sol-gel derived calcium phosphates. J SolGel Sci Technol 2009;51(3):287.

[41] Gasquères G, Bonhomme C, Maquet J, Babonneau F, Hayakawa S, Kanaya $T$, et al. Revisiting silicate substituted hydroxyapatite by solid-state. NMR Magn Reson Chem 2008;46:342.

[42] Reid JW, Pietak A, Sayer M, Dunfield D, Smith TJN. Phase formation and evolution in the silicon substituted tricalcium phosphate/apatite system. Biomaterials 2005;26:2887.

[43] Miquel JL, Facchini L, Legrand AP, Rey C, Lemaitre J. Solid-state NMR to study calcium-phosphate ceramics. Colloids Surf 1990;45:427.

[44] Jakeman R, Cheetham A, Clayden N, Dobson C. A magic angle spinning NMRstudy of the phase-diagram $\mathrm{Ca}_{3-x} \mathrm{Zn}_{x}\left(\mathrm{PO}_{4}\right)_{2}$. J Solid State Chem 1989;78:23.

[45] Obadia L, Deniard P, Alonso A, Rouillon T, Jobic S, Guicheux J, et al. Effect of sodium doping in beta-tricalcium phosphate on its structure and properties. Chem Mater 2006;18:1425. 